University of Pennsylvania Carey Law School

Penn Law: Legal Scholarship Repository

Faculty Scholarship at Penn Law

1994

\title{
A Property-Based Theory of Security Interests: Taking Debtor's Choices Seriously
}

Steven L. Harris

Chicago-Kent Law School

Charles W. Mooney Jr.

University of Pennsylvania Carey Law School

Follow this and additional works at: https://scholarship.law.upenn.edu/faculty_scholarship

Part of the Bankruptcy Law Commons, Business Law, Public Responsibility, and Ethics Commons, Commercial Law Commons, Economic Policy Commons, Economics Commons, Law and Economics Commons, Secured Transactions Commons, Securities Law Commons, and the Work, Economy and Organizations Commons

\section{Repository Citation}

Harris, Steven L. and Mooney, Charles W. Jr., "A Property-Based Theory of Security Interests: Taking Debtor's Choices Seriously" (1994). Faculty Scholarship at Penn Law. 1290.

https://scholarship.law.upenn.edu/faculty_scholarship/1290

This Article is brought to you for free and open access by Penn Law: Legal Scholarship Repository. It has been accepted for inclusion in Faculty Scholarship at Penn Law by an authorized administrator of Penn Law: Legal Scholarship Repository. For more information, please contact PennlawIR@law.upenn.edu. 


\title{
A PROPERTY-BASED THEORY OF SECURITY INTERESTS: TAKING DEBTORS' CHOICES SERIOUSLY
}

\author{
Steven L. Harris* and Charles W. Mooney, Jr.**
}

\section{INTRODUCTION}

\begin{abstract}
$\mathrm{N}$ embarking upon the revision of what many consider the most I successful commercial statute ever, we take as our "first principle" that Uniform Commercial Code Article 9 should facilitate the creation of security interests. Stated otherwise, we think the transfer of an effective security interest ought to be as easy, inexpensive, and reliable as possible. For the most part, the current version of Article 9 reflects our position: The law should not impair the ability of debtors to secure as much or as little of their debts with as much
\end{abstract}

* Professor, University of Illinois College of Law.

** Professor, University of Pennsylvania Law School. The authors are Reporters for the Drafting Committee to Revise U.C.C. Article 9 and were Reporters for the Permanent Editorial Board U.C.C. Article 9 Study Committee. The views expressed in this Article are not necessarily those of the Drafting Committee, the Study Committee, or any of the sponsors of either (the Permanent Editorial Board, the American Law Institute, or the National Conference of Commissioners on Uniform State Laws). We wish to thank Leigh Riley-Kroehmer, University of Pennsylvania Law School, Class of 1995, and Claire Menard, Georgetown University Law Center, Class of 1995, for their valuable research assistance. We also wish to thank the John M. Olin Program in Law and Economics of the University of Virginia School of Law, the Georgetown University Law Center, the University of Illinois College of Law, and the University of Pennsylvania Law School for research support.

We presented an earlier draft of this Article at a conference held in Charlottesville, Virginia, on October 15-16, 1993, sponsored by the Olin Program in Law and Economics of the University of Virginia School of Law. This draft has benefited substantially from the commentary and discussion at that conference, and especially from the comments of Paul Shupack and the input of the two designated commentators, Professors Alan Schwartz and James J. White. We also thank Edward Rubin, Dennis Patterson, Thomas Ulen, and William Vukowich for their helpful comments. Circumstances do not permit us to respond here to the published commentaries of Professors Schwartz and White. See Alan Schwartz, Taking the Analysis of Security Seriously, 80 Va. L. Rev. 2073 (1994); James J. White, Work and Play in Revising Article 9, 80 Va. L. Rev. 2089 (1994). In our Conclusion, however, we do offer some brief observations on Professor Schwartz' commentary. We must defer a more fulsome response. 
or as little of their existing and future property as they deem appropriate. ${ }^{1}$

Our position has been controversial. The nineteenth and early twentieth century saw many secured transactions struck down on the ground that they were at least potentially injurious to unsecured creditors. ${ }^{2}$ A good deal of the perceived injury stemmed from the distributional consequences of security: property subject to a security interest would be unavailable for distribution to unsecured creditors. If the debtor became insolvent, allocation of particular property to secured creditors would unjustly interfere with, and perhaps eliminate, the recovery by unsecured creditors. ${ }^{3}$ Even the original drafters of Article 9, who expressly validated future-advance and after-acquired property clauses, did so with some reluctance, apparently experiencing a discomfort with "all assets" financing that we (the authors) do not share. ${ }^{4}$

Despite widespread familiarity with Article 9 and the passage of more than three decades, this discomfort persists. Contemporary commentators have continued the tradition of expressing diffuse suspicion about the "favored" treatment the law affords to security interests. The fact that secured creditors appear to recover a larger

1 See U.C.C. §9-204(1) (1990) (providing that obligations may be secured by afteracquired collateral); id. $\$ 9-204(3)$ (providing that obligations secured by a security agreement may include future advances).

2 For a fascinating history of the judicial and legislative battles over the ability of secured creditors to reach property claimed by unsecured creditors, see 1 Grant Gilmore, Security Interests in Personal Property 5-287 (1965).

3 See, e.g., Zartman v. First Nat'l Bank, 82 N.E. 127, 128-29 (N.Y. 1907) (holding an after-acquired property clause to be ineffective at law and refusing to give effect to the clause in equity against a trustee in bankruptcy because "the result would deprive the general creditors with superior equities so far as after-acquired property is concerned, of their only chance to collect debts").

4 As the official comments explain:

The widespread nineteenth century prejudice against the floating charge was based on a feeling, often inarticulate in the opinions, that a commercial borrower should not be allowed to encumber all his assets present and future, and that for the protection not only of the borrower but of his other creditors a cushion of free assets should be preserved. That inarticulate premise has much to recommend it. This Article decisively rejects it not on the ground that it was wrong in policy but on the ground that it was not effective.

U.C.C. § 9-204 cmt. 2. 
portion of their claims in bankruptcy than do unsecured creditors has been of particular concern. ${ }^{5}$

Recent years also have seen the rise of scholarship that has subjected security interests to closer examination, often with the aid of economics, in an ongoing debate over whether secured credit is socially useful and, if so, how. Although the newer literature is considerably more rigorous than what came before, it sounds some familiar themes-reflecting fascination with, if not always concern about, the distributive effects attendant to the grant of security. We confess that we have shied from this debate until now. ${ }^{6}$ But as we begin to draft the new Article 9, we wish to draw upon this debate and also to weigh in with our own views on a "general theory" for secured transactions. We are motivated, in part, by our experiences as Reporters for the Permanent Editorial Board Article 9 Study Committee. ${ }^{7}$ Time and again the Study Committee's deliberations on particular points generated both disagreement and confusion concerning the basic policy underpinnings of Article 9. There is every reason to think that a similar fate will befall the Drafting Committee.

In this Article we identify and explain a normative basis for our first principle of secured transactions. To establish the context, Part I first rebuts the popular misconception that giving security for debt necessarily harms a debtor's unsecured creditors. A similar notion-that the incurrence of secured debt necessarily increases risk for unsecured creditors-lies at the theoretical center of the literature constituting the recent debate about secured credit, which we call the "Efficiency Literature." Although this literature may be interesting and useful, we conclude that it is

5 Grant Gilmore, the principal drafter of the original Article 9 and a consultant to the review committee, is a part of this tradition. See Grant Gilmore, The Good Faith Purchase Idea and the Uniform Commercial Code: Confessions of a Repentant Draftsman, 15 Ga. L. Rev. 605, 626-28 (1981); see also Lynn M. LoPucki, The Unsecured Creditor's Bargain, 80 Va. L. Rev. 1887, 1891 (1994) (arguing that "security enables secured creditors and debtors to extract a remedy from those who become unsecured creditors involuntarily").

6 Actually, we have not shied from the debate entirely. See John O. Honnold, Steven L. Harris \& Charles W. Mooney, Jr., Security Interests in Personal Property 562-64 (2d ed. 1992), which offers a brief critique of Alan Schwartz, A Theory of Loan Priorities, $18 \mathrm{~J}$. Legal Stud. 209 (1989).

7 The Study Committee's final report describes the background of the study, the organization and operation of the committee, and the committee's approach toward its work. PEB Study Comm., Uniform Commercial Code Article 9: Report 1-9 (Dec. 1, 1992). 
largely free of cogent support for materially modifying the current legal regime for secured transactions. We identify what appear to be an erroneous assumption and a methodological flaw pervading the Efficiency Literature; however, we have eschewed a comprehensive critique ${ }^{8}$ and have made no effort to demonstrate that all secured credit is wealth enhancing or to explain the prevailing patterns of secured financing. We are confident that American law will continue to recognize the effectiveness of security interests, and we have agreed to play a role in revising that part of the legal regulation of security interests contained in Article 9.

For our purposes it is sufficient to demonstrate, as we do in Part I, that many secured transactions may be wealth enhancing. ${ }^{9}$ Part I also considers a (more or less tongue-in-cheek) amalgam of the views of other critics of secured transactions-a "school of thought" concerning debtor-creditor law that we call "Sympathetic Legal Studies."

Part II.A examines the creation of security interests as a subset of the law governing private property. The well-accepted rights of property owners - to use and freely and effectively to alienate their property and to be secure in their ownership-form the basis of our normative theory of secured transactions. Like broader theories of property law, which generally validate the decisions of debtors to transfer their property outright, our theory generally validates the decisions of debtors to transfer their property for collateral purposes. And like the broader theories, our theory respects personal autonomy and freedom of contract. In developing our theory, we seek to put to rest any general skepticism about the value of security interests and biases against the creation and effectiveness of security interests. Alternatively, we hope to elicit from the skeptics a more explicit and principled critique of security. The normative basis for security interests grounded in property

8 For the most recent such critique, see David G. Carlson, On the Efficiency of Secured Lending, 80 Va. L. Rev. 2179 (1994).

9 Although the Efficiency Literature may provide insights into certain effects of secured credit, we have seen nothing there or anywhere else that would justify a major shift in policy. Were it clear (or even reasonably plausible) that debtors were reducing their costs of credit by securing some creditors and imposing the costs on unwilling (or unwitting) third parties, adjustments might be warranted. In Part II.B, infra, we address how the revised Article 9 might deal with costs of secured credit that people generally agree are imposed on third parties. 
concepts does not, of course, justify every detail and nuance of the legal regime. But the property analysis does account for the general proposition that parties are entitled to allocate their resources among their creditors as they see fit.

Not all property interests are identical. Part II.B focuses on the peculiarities of security interests in personal property that might justify special legal regulation of their creation and effectiveness. That Section also addresses the extent to which certain important exceptions to the principle of free and effective alienation of property-namely, fraudulent transfer law and requirements for public notice of certain nonpossessory interests-can reduce or eliminate any costs that secured transactions may impose upon third parties.

The skepticism surrounding secured credit peaks when the discussion turns to bankruptcy. Although bankruptcy creates even more exceptions to property law principles at the margin, bankruptcy nonetheless accepts nonbankruptcy property law as its baseline. Part III explores briefly the relationship between bankruptcy policy and nonbankruptcy property law, in particular the nonbankruptcy law of secured transactions.

\section{In Search of a General Theory of Secured \\ TRANSACTIONS: ECONOMIC ANALYSIS AND Sympathetic Legal Studies}

\section{A. The Efficiency Literature and the "Puzzle" of Secured Debt}

Contributors to the Efficiency Literature generally mark its beginning with an article written by Professors Thomas Jackson and Anthony Kronman in $1979 .{ }^{10}$ Although the purpose of their

10 Thomas H. Jackson \& Anthony T. Kronman, Secured Financing and Priorities Among Creditors, 88 Yale L.J. 1143 (1979). The discussion in the text that follows is indebted to the thoughtful intellectual history of the pre-1989 Efficiency Literature found in Paul M. Shupack, Solving the Puzzle of Secured Transactions, 41 Rutgers L. Rev. 1067, 1073-83 (1989) [hereinafter Shupack, Solving]. The Efficiency Literature includes the following articles, in addition to those by Jackson and Kronman and Shupack: Barry E. Adler, An Equity-Agency Solution to the Bankruptcy-Priority Puzzle, 22 J. Legal Stud. 73 (1993); Richard L. Barnes, The Efficiency Justification for Secured Transactions: Foxes with Soxes and Other Fanciful Stuff, 42 Kan. L. Rev. 13 (1993); James W. Bowers, Whither What Hits the Fan?: Murphy's Law, Bankruptcy Theory, and the Elementary Economics of Loss Distribution, 26 Ga. L. Rev. 27 (1991); F.H. Buckley, The Bankruptcy Priority Puzzle, 72 Va. L. Rev. 1393 (1986); Thomas H. Jackson \& Alan Schwartz, Vacuum of Fact or Vacuous Theory: A Reply to Professor Kripke, 133 U. Pa. L. Rev. 987 (1985); Homer 
article was "to develop a unified theory that explains several of the most important priority rules in Article 9," "Jackson and Kronman undertook their task in the context of the debtor's insolvency. Taking the position that a theory of Article 9 priorities could be developed only after considering several more fundamental questions, they asked: "Why does the law permit secured financing in the first place? Put differently, why does the law allow a debtor to prefer some creditors over others by securing their claims, instead of requiring all creditors to share ratably in the debtor's estate?"12 These questions may account for what is at best confusion, and at worst a methodological error, that runs through much of the Efficiency Literature. Like many before them, Jackson and Kronman examined the phenomenon of secured credit in the context of its distributional effects, specifically, its effects on the expected return to the unsecured creditors of an insolvent debtor.

As we explain further below, the well-known fact that collateral enables creditors to recover more than a pro rata share of an insolvent debtor's estate reveals only part of the picture. Moreover, the assumption that the creation of security interests-or any other voluntary activity, for that matter-imposes costs on third parties, produces inefficient results, or otherwise is not socially optimal (or

Kripke, Law and Economics: Measuring the Economic Efficiency of Commercial Law in a Vacuum of Fact, 133 U. Pa. L. Rev. 929 (1985); Saul Levmore, Monitors and Freeriders in Commercial and Corporate Settings, 92 Yale L.J. 49 (1982); Randal C. Picker, Security Interests, Mis behavior, and Common Pools, 59 U. Chi. L. Rev. 645 (1992); Alan Schwartz, The Continuing Puzzle of Secured Debt, 37 Vand. L. Rev. 1051 (1984); Alan Schwartz, Security Interests and Bankruptcy Priorities: A Review of Current Theories, 10 J. Legal Stud. 1 (1981) [hereinafter Schwartz, Review]; Schwartz, supra note 6; Robert E. Scott, A Relational Theory of Secured Financing, 86 Colum. L. Rev. 901 (1986); Paul M. Shupack, Defending Purchase Money Security Interests Under Article 9 of the UCC from Professor Buckley, 22 Ind. L. Rev. 777 (1989); George G. Triantis, Secured Debt Under Conditions of Imperfect Information, 21 J. Legal Stud. 225 (1992); James J. White, Efficiency Justifications for Personal Property Security, 37 Vand. L. Rev. 473 (1984). To the foregoing one must add the articles and commentary appearing in this Symposium. Our list may not be exhaustive; we apologize for any omissions. The list also omits finance and economics articles that have not appeared in legal journals.

11 Jackson \& Kronman, supra note 10, at 1146.

12 Id. Jackson and Kronman went on to ask, "[E]ven assuming there is no principled objection to debtor-created preferences of this sort, what explains the widespread use of secured financing, and why do some classes of creditors typically finance on a secured basis and others on an unsecured one?" Id. 
even useful) does not compel the conclusion that the law should prohibit that activity.

Jackson and Kronman concluded that a security interest can reduce a secured creditor's cost of monitoring the debtor's behavior, thereby benefiting not only the secured creditor but also the debtor and other creditors. ${ }^{13}$ Unsatisfied with this explanation, Professor Alan Schwartz next posed what has become known as the "puzzle" of secured credit, setting the table for a feast of efforts to "explain" this common phenomenon. ${ }^{14}$ Schwartz argued that, in a perfect market, ${ }^{15}$ secured creditors would charge lower interest rates because of the lower risks resulting from receiving collateral, while the cost of unsecured credit (i.e., the risk premium that a debtor must pay) would rise so as to match exactly the savings obtained by giving collateral to the secured creditor. ${ }^{16}$ Schwartz reasoned that giving security in a perfect market is a zero-sum game. Losers offset winners, and debtors gain nothing by giving security. But, as everyone would acknowledge, debtors do give security in the real world. Thus, the "puzzle" of secured debt emerged: What are the benefits of secured credit in an imperfect market (the real world), given that there are no benefits in a perfect market? ${ }^{17}$

13 Id. at $1153-55$.

14 Schwartz, Review, supra note 10, at 7-9.

15 Schwartz made the following assumptions: "[C]reditors (i) can learn of and react to the existence of security; (ii) can calculate risks of default reasonably precisely; (iii) are risk-neutral; and (iv) have homogeneous expectations respecting default probabilities." Id. at 7.

16 The prediction generated by Schwartz' model is similar to that made by the New York Court of Appeals more than eight decades ago: "If it is understood that a corporate mortgage given by a manufacturing corporation may take everything except accounts and debts, such corporations, with a mortgage outstanding, will have to do business on a cash basis or cease to do business altogether." Zartman v. First Nat'l Bank, 82 N.E. 127, 128 (N.Y. 1907).

17 For some, Schwartz' puzzle turns out to be a puzzle of unsecured debt: Why do some unsecured creditors extend credit when their risk premiums do not offset the debtor's cost savings? See Adler, supra note 10, at 74 ("The puzzle is that secured credit appears valuable but is not ubiquitous. The solution should address this 'ubiquity puzzle' directly."); Shupack, Solving, supra note 10, at 1091 ("[T]he puzzle is not one of secured transactions, but one of unsecured debt.").

We have found another puzzle-one concerning the Efficiency Literature itself: Why does it dwell on personal property security alone? How does one distinguish, for these purposes, the mortgage on Blackacre from the security interest in an aircraft, or in inventory? Schwartz originally posed his puzzle in the specific context of short-term debt, 


\section{B. Does Secured Credit Necessarily Transfer Wealth from Unsecured Creditors to Secured Creditors?}

The distributional effect of secured credit-the reallocation of assets from unsecured to secured creditors-is central to Schwartz' puzzle and to the many efforts to solve it. Schwartz postulated that "unsecured creditors will charge higher interest rates because the pool of assets available to satisfy their claims has shrunk."18 To the extent that collateral secures antecedent debt, Schwartz is correct. But when new value is extended on a secured basis, the extension of secured credit does not shrink the pool of assets available for the satisfaction of unsecured claims. Suppose, for example, that at a particular time ("T,") the debtor ("D") has assets of $\$ 400$ and unsecured debt of $\$ 300$. The unsecured creditor ("UC") can look to the $\$ 400$ pool of assets for satisfaction of its claim. Next suppose that (also at $\mathrm{T}_{0}$ ) D borrows an additional $\$ 100$ from another creditor ("SP"), this time giving collateral worth $\$ 100$ to secure that loan. ${ }^{19}$ Now $\mathrm{D}$ has assets of $\$ 500$ (the additional $\$ 100$ being the proceeds of the loan), $\$ 100$ of which would be allocated to pay the secured creditor were default also to occur at $\mathrm{T}_{0}$. The same $\$ 400$ asset pool that existed before the secured loan was extended remains available to satisfy UC's claim thereafter. Clearly, neither

happily explaining that long-term debt normally is secured by real estate or long-lived industrial equipment. Schwartz, Review, supra note 10, at 4. Much of the Efficiency Literature does not, however, focus on that distinction. Because examples of long-term unsecured debt abound, we see no reason why the questions (and answers) surrounding the presence of both secured and unsecured credit must differ depending on whether the collateral consists of personal or real property.

18 Schwartz, Review, supra note 10 , at 7.

19 We realize that the example may run counter to Schwartz' conclusion that, in a perfect market, there is no reason to expect that $\mathrm{D}$ would have given collateral to secure the additional $\$ 100$ loan. On the other hand, our example may be consistent with perfectmarket assumptions if it is merely one of the random cases of secured credit. See Shupack, Solving, supra note 10, at 1086 (arguing that in a perfect market all creditors would act as one and the existence or nonexistence of security interests would be random). Regardless, as explained below, our example is consistent with an assumption about the credit markets that everyone acknowledges is accurate: that credit desired by a borrower or buyer commonly is available only if the borrower or buyer gives collateral. In refuting Schwartz' claim that the transfer of collateral (or anything else) for new equivalent value necessarily depletes the pool of assets available for satisfying unsecured claims, we have adopted this accurate assumption instead of relaxing the perfect-market assumptions systematically until identifiable elements of an imperfect market make security interests "appear." 
D's secured borrowing (nor any other transfer of D's property) for equivalent new value depletes the asset pool at $\mathrm{T}_{0}{ }^{20}$

The same cannot necessarily be said with respect to the asset pool at any given time in the future. The value of D's assets may decline over time, for one or more of innumerable reasons. Equipment may deteriorate or become obsolete; inventory may go out of fashion; a major customer may go out of business. If, at a future time (" $\mathrm{T}_{1}$ "), D becomes insolvent and is liquidated (or reorganized), UC's recovery may be less if $\mathrm{D}$ gave security for the new $\$ 100$ loan than if the new loan had been unsecured. ${ }^{21}$ For example, assume that the amount of D's debt remains constant at $\$ 400$, but that at $\mathrm{T}_{1} \mathrm{D}$ has become insolvent, and the value of its assets has declined from $\$ 500$ to $\$ 300$ (i.e., the asset value at $T_{1}$ equals $60 \%$ of the value at $T_{0}$ ). Had $D$ incurred the new $\$ 100$ debt on an unsecured basis, each unsecured creditor, UC and SP, would have recovered $75 \%$ of its claim (\$300 (assets) / $\$ 400$ (unsecured claims) $=75 \%) .{ }^{22}$ But, because the new $\$ 100$ debt was secured, UC will recover only $71 \%$ of its claim, whereas SP will recover $88 \%$ of its

20 Securing antecedent debt would deplete the pool of assets available for UC, of course, as could payment of all or a portion of unsecured debt.

Schwartz' apparent failure to consider the increase in D's assets that results from the loan is consistent with the improbable example that he offers to illustrate the "puzzle." $\mathrm{He}$ assumes that "a firm wants to borrow $\$ 200$ from two risk-neutral creditors . . . It has $\$ 100$ in available assets and both creditors assume this value to be stable over time." Schwartz, Review, supra note 10, at 8. In Schwartz' example, the loan proceeds inexplicably vanish at or about the time that the loans are made, and the creditors are willing to extend credit despite their belief that the debtor is insolvent at the time of the loans and will remain insolvent thereafter. Professor Kripke made a similar criticism by arguing that contributors to the Efficiency Literature failed to take into account that security interests facilitate credit for the acquisition of new assets that otherwise would not be given. Kripke, supra note 10, at 936, 939-41. Professors Jackson and Schwartz responded that Kripke confused the question of whether a debtor would acquire a new asset with the question of whether a debtor would do so by borrowing on a secured or unsecured basis. See Jackson \& Schwartz, supra note 10, at 994.

21 The statement in the text assumes that the grant of security itself does not affect either the probability of liquidation or the value of the unencumbered assets.

22 The examples that we discuss here assume that insolvent debtors are liquidated in a collective proceeding, that each unsecured creditor receives a pro rata share of the debtor's unencumbered assets, and that the liquidation distribution constitutes UC's entire recovery. In reality, many insolvent debtors operate for long periods of time and continue to pay their unsecured creditors; thus, those creditors may recover substantially more than their assumed share of an insolvent debtor's estate. 
claim. ${ }^{23}$ UC would have recovered more if the new $\$ 100$ debt had been incurred on an unsecured basis. The reduction in UC's return is attributable to the diminution in asset values, which probably is independent of the grant of security. Contrary to Schwartz' assertion, the grant of security did not itself deplete the asset pool.

Of course, UC's liquidation distribution does not tell the whole story. What also matters to UC is the present expected value (at $\mathrm{T}_{0}$ ) of UC's claim. Holding all other variables constant, a reduction in the value of UC's recovery in a liquidation at $\mathrm{T}_{1}$ correspondingly reduces the present expected value of UC's claim. ${ }^{24} \mathrm{It}$ appears, then, that UC would have been better off had the new $\$ 100$ loan been extended on an unsecured basis.

The Efficiency Literature is replete with analyses like the foregoing, which compare the plight of unsecured creditors using the alternative assumptions of (a) an additional secured loan and (b) an additional unsecured loan in the same amount. But these are not the alternatives that many real-world debtors face. Experience tells us that, in many cases, the debtor's actual choice is between borrowing on a secured basis and not borrowing at all (or, in some cases, borrowing less money on an unsecured basis).

If we return to our example and make one plausible additional assumption-that SP would not have extended the new $\$ 100$ of credit without collateral-then there is no basis to infer any necessary reduction in the present value of UC's claim resulting from D's giving security to SP. ${ }^{25}$ This is so because the benefits that UC

23 SP will recover $\$ 60$ from its collateral (assuming the assets have depreciated ratably). The remaining $\$ 240$ of assets will be divided pro rata between SP, with an unsecured claim of $\$ 40$, and UC, with an unsecured claim of $\$ 300$ : $\$ 240$ (assets) / $\$ 340$ (unsecured claims) = $71 \%$. UC will recover $\$ 213$ (71\% of $\$ 300)$, and SP will recover $\$ 88$ (\$60 (collateral value) $+\$ 28(71 \%$ of $\$ 40))$.

24 For a more formal explanation of the bankruptcy priority irrelevance proposition, see Buckley, supra note 10 , at 1397-1404.

25 Implicit in this assumption is another assumption, concerning the accuracy of which we have little doubt: the legal regime will continue to give effect to consensual security interests. Indeed, denying legal effectiveness to security interests altogether would set the stage for transactional formalism and encourage wasteful strategic behavior. Modern credit and financial markets implicate a vast spectrum of transfers of intangible as well as tangible property. Secured purchase-money financing and secured accounts and inventory financing scratch only the surface of the enormous variety of transactions. As Professors Kripke and White have pointed out, if security interests became legally ineffective, other mechanisms likely would emerge as substitutes; line-drawing would become difficult and increasingly pervasive. See Kripke, supra note 10, at 975-79; White, supra note 10, at 502- 
derives from SP's having made additional credit available to D easily could outweigh the costs arising from the additional risks created by the transfer of collateral to SP. To see how UC might be better off if $\mathrm{D}$ borrows on a secured basis than if $\mathrm{D}$ does not borrow at all, let us return to our example. We saw that if SP extends credit of $\$ 100$ and receives security, then UC's distribution upon D's liquidation would be $71 \%$ of its $\$ 300$ claim, or $\$ 213$. Assuming that the probability of default is $3 \%,{ }^{26}$ the expected value of UC's claim is $\$ 297.39 .{ }^{27}$ If the new credit of $\$ 100$ is not extended and the assets all depreciate at the same rate, then the distribution to UC at $\mathrm{T}_{1}$ would be $80 \%$ of its $\$ 300$ claim, or $\$ 240,{ }^{28}$ and the present expected value of UC's claim would be $\$ 298.20 .^{29}$

The calculations do not take into account the very real possibility that the additional $\$ 100$ loan might reduce the likelihood of D's insolvency. Although they indicate that $\mathrm{UC}$ is better off if $\mathrm{D}$ does not borrow at all, the calculations assume that the probability of D's becoming insolvent is unaffected by the availability of additional credit. As he has done previously in writing, ${ }^{30}$ Schwartz acknowledged at the 1993 Olin Conference ("Charlottesville conference") that the extension of additional credit might enable a debtor to increase its wealth. He also acknowledged that an increase in the debtor's wealth could reduce the probability of default. Using the example under discussion here, Schwartz observed that, in order to increase the expected monetary value of

08; see also U.C.C. § 9-204 cmt. 2 (suggesting that attempts to protect a cushion of free assets for unsecured creditors were not effective under pre-U.C.C. law); supra note 4 (setting out relevant text of $\S 9-204 \mathrm{cmt} .2$ ).

Moreover, if security interests are suspect on distributional grounds, then involuntary judicial liens a fortiori are suspect on the same grounds. That suspicion would call into question the propriety of permitting judicial enforcement of unsecured contract and tort claims in a way that gives one creditor's claim priority over that of another.

26 We realize that it is meaningless to "estimate" the likelihood of a fictional debtor's failure. Anecdotal evidence suggests that the default rate of debtors who give security is apt to be lower than the $3 \%$ rate we have chosen.

27 The expected value of UC's claim is the sum of the expected recovery if D does not become insolvent $((0.97)(\$ 300)=\$ 291)$ plus the expected recovery from a liquidation $((0.03)(\$ 213)=\$ 6.39)$, or $\$ 297.39$.

28 This distribution is calculated as follows: $\$ 240$ (or $60 \%$ of original assets of $\$ 400$ ) / $\$ 300$ (unsecured claim) $=80 \%$.

$29(0.97)(\$ 300)+(0.03)(\$ 240)=\$ 298.20$.

30 Jackson \& Schwartz, supra note 10, at 994 ("No one denies that a debtor can use borrowed funds to increase its net wealth."). 
UC's claim, the extension of additional secured credit would need to reduce the default rate by more than $31 \%$ (that is, from $x$ to less than $0.69 x$ ). In Schwartz' opinion, the cases in which an extension of additional secured credit (credit that would not have been extended on an unsecured basis) would decrease the probability of default by more than $31 \%$ are too scarce to support an argument for the general efficiency of secured credit.

Perhaps we are unduly timorous, but we are loath to draw any conclusions based on the $31 \%$ figure. That figure derives from the particular example we have chosen, as supplemented by some assumptions that Schwartz in troduced at the Charlottesville conference. Had we, for example, held everything constant but assumed that SP extended a smaller secured loan, the 31\% figure likewise would have decreased. ${ }^{31}$ The same consequence would have followed had Schwartz assumed that D's assets decreased in value by more than the assumed $40 \%$, or that SP's collateral decreased proportionately less than the other assets. Of course, other modifications (such as securing SP's new loan with assets worth more than the amount of the loan) would cause the $31 \%$ figure to increase. Given the divergent circumstances in which secured credit is extended, we doubt that any figure could be considered representative.

But even assuming that the $31 \%$ reduction is typical, there is no basis for accepting Schwartz' assertion that a reduction of this magnitude would occur only in rare cases. Given the assumed low probability of default (0.03) if no additional credit is forthcoming, it seems quite plausible that the extension of new credit could reduce the default probability by less than 0.01 , from 0.03 to 0.0207

31 For example, had SP extended a new loan in the amount of $\$ 50$ (rather than $\$ 100$ ), the present expected value of UC's claim would have increased if the additional credit had reduced the probability of default by more than $20 \%$ (rather than $31 \%$ ). Assume that at $\mathrm{T}_{0}$ D's assets are $\$ 450$, while total debt equals $\$ 350$ ( $\$ 300$ to UC and $\$ 50$ to SP). At $\mathrm{T}_{1}$, the value of D's assets declines by $40 \%$ to $\$ 270$ (60\% of $\$ 450)$. SP will recover $60 \%$ of its $\$ 50$ claim from the collateral. The remaining property will be distributed pro rata to UC and SP at a $75 \%$ rate $(\$ 240$ (total remaining asset value) $/ \$ 320$ (total remaining debt) $=75 \%$ ). UC will recover $\$ 225$ (or $75 \%$ of $\$ 300$ ). SP will recover $\$ 45$ (that is, $\$ 30$ (or $60 \%$ of $\$ 50$ ) + $\$ 15$ (or $75 \%$ of $\$ 20)$ ). The present expected value of UC's claim when the probability of default is decreased by $20 \%$ to 0.024 is $\$ 298.20((0.976 \times 300)+(0.024 \times 225))$, which equals the present expected value of UC's claim had no secured credit been obtained. See supra note 29. 
(i.e., $0.69 \times 0.03$ ). Recall that SP's loan would increase D's (potentially productive) assets by $25 \%$ (from $\$ 400$ to $\$ 500$ ) at $\mathrm{T}_{0}{ }^{32} \mathrm{D}$ 's acquisition of $\$ 100$ in loan proceeds that were not otherwise available could enable D to pursue new projects, buy additional inventory or more efficient equipment, employ additional workers, or otherwise behave in a way that would decrease the likelihood that D would fail and would enhance the prospects that D would become more profitable. ${ }^{33}$

Reducing the probability of default is not the only way in which the new credit might increase the expected value of UC's claim. The value will increase if $\mathrm{D}$ uses a portion of the loan proceeds to pay down its debt to UC. ${ }^{34}$ If UC is a trade creditor whose continued relationship with $\mathrm{D}$ enhances the value of the business, SP might even require that $\mathrm{D}$ apply the proceeds in this manner.

Moreover, the $\$ 100$ loan from SP could confer benefits on UC over and above the increased expected value of the claim. Suppose, for example, that UC is a "typical" trade creditor who extends 30-day unsecured credit in connection with its sales of goods or services to D. UC seeks to make its way in the marketplace by selling at a profit, not by funding itself at one rate and relending at another, higher rate. But as a "typical" secured financer of inventory and receivables, SP may indeed hope to earn a profit

32 D's assets would, of course, be reduced over time by payments of principal and interest on SP's claim.

33 One might be inclined to argue that a reduction of probability by even 0.01 would be unlikely, given a very low default rate even in the absence of new credit. The most costeffective means of reducing the probability of default would already have been taken. Once the rate is reduced to a low figure, such as the assumed $3 \%$, additional reductions would be very costly. There are two responses to this argument. First, anecdotal evidence shows that (i) if the default probability is not very low, it is unlikely that anyone will extend credit at all-even with security-and (ii) even in the face of low defaul probabilities, much credit that is extended would not be extended without security. Second, as we explain below, the extension of otherwise available credit can benefit UC even if the default probability is not reduced.

34 For every dollar paid to UC in a nonpreferential transfer, there is a 1.0 probability of recovery. Thus, if D pays UC $\$ 20$ at $\mathrm{T}_{0}$, the expected value of UC's claim (assuming a 0.03 liquidation probability) is $((1.0)(\$ 20)+(0.97)(\$ 280)+(0.03)(228 / 320)(\$ 280))$, or $\$ 297.58$, which compares favorably with $\$ 297.39$, the expected value of UC's claim if it receives no payments. The liquidation recovery assumes that the $\$ 480$ asset base ( $\$ 500$ less the $\$ 20$ payment to UC) is worth only $60 \%$ of that amount ( $\$ 288)$ at liquidation, and that $\mathrm{SP}$ is entitled to its collateral value $(\$ 60)$ and has an unsecured claim of $\$ 40$. Total unsecured claims equal $\$ 320$, and total unencumbered assets equal $\$ 228$. 
on the lending transaction. When the alternative is no credit at all for $\mathrm{D}$ (and fewer sales for UC), UC may prefer strongly that D obtain secured credit from SP in order to keep D's payables current (i.e., to pay UC or buy more goods or services from UC). Assuming that UC has a $10 \%$ profit margin, two additional transactions of $\$ 300$ each with $\mathrm{D}$ would produce profits of $\$ 60$, an amount equal to UC's entire expected loss on its $\$ 300$ unsecured claim if $\mathrm{D}$ were certain to fail. Assuming further that $\mathrm{UC}$ is a repeat player with many customers such as $\mathrm{D}$, and given the assumed $97 \%$ probability that each customer will pay its debts, it is easy to see the potential benefits to UC of otherwise unavailable secured credit extended to its customers. ${ }^{35}$

The benefits of credit that becomes available as a result of giving security also must be viewed from the broader perspective of Kaldor-Hicks efficiency. ${ }^{36}$ Those benefits typically extend far beyond $\mathrm{D}$ and its creditors. Indeed, borrowed funds that $\mathrm{D}$ spends have a multiplier effect when the recipients of those funds spend or invest them. ${ }^{37}$

One of the central questions that the Efficiency Literature addresses is whether the granting of security under current law promotes efficiency. To date the Efficiency Literature has not provided any consensus theory concerning the efficiency of secured credit; however, several contributors who followed Schwartz claimed a solution of sorts to the "puzzle" after having accepted it

35 There are many other stories that could explain how secured credit that would be unavailable without a debtor's giving collateral can benefit the debtor's unsecured creditors. We thank Professor Shupack for sharing some of these stories for us. For example, if a debtor is hopelessly insolvent and has very few assets, its unsecured creditors have little to lose because their expected recovery is either nonexistent or tiny. An extension of secured credit that enables the debtor to pursue a potentially profitable project may represent the unsecured creditors' only realistic opportunity for a meaningful recovery on their claims. Note that in recent years government officials have been complaining about excessively "tight" credit policies adopted by banks, while bemoaning the fate of small businesses whose needs for cash are not being satisfied.

36 As used in the Efficiency Literature, efficiency generally means the Kaldor-Hicks concept of efficiency: If the losses (costs) imposed on society by a particular legal rule are more than offset by the gains (benefits), the rule is efficient even if the winners do not compensate the losers. See Richard A. Posner, Economic Analysis of Law 13-14 (4th ed. 1992).

37 Extensions of credit can increase the output of goods and services as well as the supply of money. See Edwin Mansfield, Economics 273, 283 (6th ed. 1989). 
largely on its own terms. ${ }^{38}$ Our analysis acknowledges that UC and other unsecured creditors are better off if their debtor incurs unsecured rather than secured debt (on the assumption that the present value of each unsecured creditor's claim in insolvency would be slightly larger in the former case). Nevertheless, unsecured creditors can be better off if their debtor borrows on a secured basis than if their debtor is unable to borrow at all. ${ }^{39}$ In short, extension of secured credit may be a "second best" result for unsecured creditors. ${ }^{40}$

We agree with those who doubt that any single explanation could be adequate to address the efficiency of secured transactions across

38 See, e.g., Buckley, supra note 10, at 1469 (arguing that security reduces screening costs and reduces risk but increases monitoring inefficiencies, and that a debtor's management is best suited to determine when giving security maximizes value); Picker, supra note 10, at 678-79 (arguing that security interests eliminate duplicative monitoring of creditor misbehavior); Scott, supra note 10, at 931-33 (arguing that security given to dominant "relational" creditor results in cost savings); White, supra note 10, at 491-94 (arguing that differences in risk aversion among creditors explain why some take security and some do not).

39 This point applies equally to all unsecured creditors, whether their claims arise from a contract (e.g., trade creditors who have sold goods or provided services to the debtor on unsecured credit) or a tort. Although the tort creditor lacks the trade creditor's power to choose its debtors, an increase or decrease in the debtor's wealth has a similar beneficial or detrimental effect on each unsecured creditor regardless of the nature of the claim.

40 Schwartz' writings have missed this point entirely. His initial contribution to the Efficiency Literature observes: "A standard authority asserts that firms that pose a nonnegligible risk of default often "cannot obtain credit on an unsecured basis .... In order to make a loan, lenders require security so as to reduce their risk of loss.' " Schwartz, Review, supra note 10, at 7 n.23 (quoting James C. Van Horne, Financial Management and Policy 458 (4th ed. 1977)) (alteration in original). Schwartz rejected this proposition because it "presupposes that creditors would refuse loans rather than lend unsecured at higher interest rates. The assumption is common but undefended. Its validity is not relevant to the analysis about to be made, which focuses on the response of unsecured creditors to the existence of security." Id. Schwartz apparently believed that the inability of a debtor to obtain credit does not adversely affect the debtor's unsecured creditors. Had he believed otherwise, then the availability of credit conditioned on the giving of security would have been relevant to his analysis of the unsecured creditors' responses to the security (and the credit extension). He later acknowledged that borrowed funds can be used by a debtor to "increase its net wealth." Jackson \& Schwartz, supra note 10, at 994 . From these two propositions Schwartz would be forced to conclude that an increase in a debtor's net wealth has no effect on the debtor's unsecured creditors. Obviously, Schwartz failed to see that a debtor's obtaining credit can affect its unsecured creditors and that the "validity" of the "common but undefended" assumption that credit sometimes is unavailable without security was (and is) central to an understanding of the effects of secured credit on unsecured creditors. Schwartz' spoken comments at the Charlottesville conference suggest that he now concedes the point. 
the board. ${ }^{41}$ And we share Professor Paul Shupack's skepticism that economic models will generate insights powerful enough to resolve important questions of public policy. ${ }^{42}$ Whether, in any given case, the benefits to unsecured creditors do outweigh the costs turns on a host of factors, some of which have been identified in the Efficiency Literature. Whether the benefits of secured credit outweigh its costs in a few, many, or most of the circumstances in which security interests are granted is an empirical question that cannot be answered with any certainty using existing information. ${ }^{43}$

In the absence of empirical data it is also impossible to conclude whether giving security generally transfers wealth from unsecured creditors to secured creditors. Research that focuses only on creditors of debtors that actually become insolvent cannot possibly answer the question; everyone knows that collateral provides a comparative advantage to the secured creditor in that situation. ${ }^{44}$ But once one acknowledges that in the real world a substantial amount of credit would not be extended without collateral and that

41 See, e.g., Picker, supra note 10, at 650 ("[W]e would be surprised if secured credit played the same role in all transactions. It almost surely does not."); Scott, supra note 10, at 912 ("It is unlikely that a single explanation can rationalize all of these various forms of security.").

42 See Shupack, Solving, supra note 10, at 1121-24.

43 This point was made in Paul M. Shupack, Defining Purchase Money Collateral, 29 Idaho L. Rev. 767 (1993):

The transfer [of security], by itself, has no necessary economic consequences. Economic analysis of secured transactions reveals a risk of wealth transfer. That risk, and the accompanying economic costs, may, as a matter of economic fact, be outweighed by the benefits that flow to debtors and creditors taken together resulting from having secured credit and [purchase-money security interest] credit available to them. The question is empirical in nature, and a proper answer requires information that we lack.

Id. at 781 .

44 Examining transactions solely in light of their expected effects in a future insolvency is not likely to shed light on anything other than the operation of various distributional principles. For example, the extension of unsecured credit also could result in UC's receiving a lower distribution than if the credit had not been extended. Using our assumptions, had SP extended unsecured credit, UC would have received a distribution equal to $75 \%$ of its claim rather than the $80 \%$ that it would have received had the new credit of $\$ 100$ not been extended at all. See supra text accompanying note 22 . Indeed, whenever credit (even unsecured credit) is extended to a solvent debtor with existing creditors and the debtor subsequently becomes insolvent, those creditors may well be worse off by virtue of the new extension of credit - the assets have been dissipated and there is yet another mouth to feed. But these results alone tell us nothing general about the aggregate social benefits of credit. 
most recipients of secured credit do not become insolvent, benefits of secured credit appear-benefits that accrue to unsecured creditors and must be weighed against the costs imposed on those creditors in the comparatively few cases of insolvency.

Secured transactions are neutral. Like many types of transactions in property (and human behavior generally), security interests can foster both the good and the bad for debtors and third parties. Even if it cannot be proved that secured transactions necessarily have beneficial results, secured transactions can and sometimes do promote efficiency and social welfare. To the extent that secured transactions bear a tarnished reputation from inferences about the general effects of secured transactions, drawn solely from observing the effects in insolvencies, their good name should be cleared.

\section{Secured Transactions and Other Transfers of Property Compared}

The securing of debt is similar to a vast array of other voluntary transactions in which a debtor may dispose of its property. This Section compares two other transactions-the payment of debt and the sale of assets-to secured loans. As we shall see, payments and asset sales are like secured loans in that they may impose costs on unsecured creditors that exceed any attendant benefits. But, also like secured loans, these other transactions may redound to the net benefit of unsecured creditors. Many of the questions about secured transactions that the contributors to the Efficiency Literature and the adherents to Sympathetic Legal Studies have raised also might be raised with respect to payments and asset sales. Curiously, they have not been.

Consider the payment by a solvent debtor (again, "D") of a debt owed to an unsecured creditor ("UC-1"), leaving another unsecured creditor ("UC-2") unpaid. Immediately after the payment $\left(\right.$ at $\mathrm{T}_{0}$ ), if we hold other factors constant, UC-2's expected recovery actually will increase upon D's payment to UC-1 at $\mathrm{T}_{0 .}{ }^{45}$

45 Assume, for example, that $\mathrm{D}$ had assets of $\$ 400$ and unsecured debt of $\$ 300$ (\$100 owed to UC-1 and $\$ 200$ owed to UC- 2 ) at $T_{0}$ and that by $T_{1}$ D's assets have shrunk to $\$ 240$ ( $60 \%$ of their former value). The aggregate distribution to UC-1 and UC-2 would be $\$ 240$, or $80 \%$ of their claims $(\$ 240 / \$ 300=80 \%)$. Assuming a 0.03 probability of default, UC-2's expected recovery would be $\$ 198.80$ (or $(0.97)(\$ 200)+(0.03)(\$ 160)$ ). 
This outcome merely recognizes that the incurrence of the debt to UC-1 itself exposed existing creditors (here, UC-2) to a risk of a lower distribution in the event of future insolvency; payment to UC-1 simply puts matters where they were just prior to UC-1's extension of credit. The same result would occur if, instead of paying UC-1, D secured UC-1's claim with collateral that did not decline in value or declined proportionately less than the unencumbered assets; that is, in this case, UC-2 would be better off if D secured UC-1's claim with nondepreciating collateral than if it did not.

Just as a debtor's receipt of new credit may work to the advantage of the debtor's existing creditors by reducing the risk of default, so D's loss of the use of the assets transferred to UC-1 may disadvantage UC-2 by increasing the risk of default. ${ }^{46}$ Securing, rather than paying, UC-1 leaves the assets available for D's use and seems likely to increase the risk of default to a lesser extent than payment would (or perhaps not at all). Just as one needs additional information to determine whether UC-2 is better off if D pays UC-1 at $\mathrm{T}_{0}$ rather than leaves UC-1 unpaid, so one cannot determine whether UC-2 is better off if D secures UC-1's claim rather than pays it. Both determinations turn on facts that cannot be known in the abstract, including the extent to which any given transaction affects the risk of default and (in the case where D gives security) the extent to which UC-1's collateral declines in value relative to $\mathrm{D}$ 's unencumbered assets.

Another useful means of considering how a payment to one unsecured creditor affects other unsecured creditors is to examine the consequences of D's decision to pay UC-1 instead of paying

Now assume in addition that at $\mathrm{T}_{0} \mathrm{D}$ paid UC-1 in full ( $\left.\$ 100\right)$, leaving assets of $\$ 300$ and debt owed to UC- 2 of $\$ 200$. If the remaining $\$ 300$ of assets then shrink to $\$ 180$ (60\% of their former value) by $\mathrm{T}_{1}$, the distribution to UC-2 will be $\$ 180$, or $90 \%$ of its claim ( $\$ 180$ / $\$ 200=90 \%)$. Assuming a 0.03 probability of default, UC-2's expected recovery would be $\$ 199.40$ (or $(0.97)(\$ 200)+(0.03)(\$ 180))$ - or $\$ 0.60$ more than its expected recovery had UC-1 not been paid. In effect, D retired the debt to UC-1 with assets that had not yet been devalued. Concerning the effect on UC-2 of D's payment to UC-1 when D is insolvent, see infra note 48 .

46 Under the facts of the example in note 45 , supra, if the payment to UC- 1 more than doubles the probability that D will default on its obligation to UC-2, then the payment reduces UC-2's expected recovery. For example, if the payment increases the probability of default from 0.03 to 0.07 , then the payment reduces UC-2's expected recovery from $\$ 198.80$ (or $(0.97)(\$ 200)+(0.03)(\$ 160))$ to $\$ 198.60$ (or $(0.93)(\$ 200)+(0.07)(\$ 180))$. 
UC-2. By virtue of that decision, UC-1 received $100 \%$ of its claim at $T_{0}$, leaving UC-2 to receive only a fraction of its claim in liquidation at $T_{1}$. (A similar, but less pronounced, effect would result from D's decision to give security to SP for a new loan instead of paying or securing an existing creditor.) The law does, of course, respect payments by solvent debtors to their creditors even in the absence of pro rata payments to other creditors. As far as we know, no one has suggested that fraudulent transfer law should reach so far as to invalidate such payments. ${ }^{47}$

Payment of an antecedent debt by an insolvent debtor is another matter. Any payment at $\mathrm{T}_{0}$ clearly reduces the pool of assets available to the remaining unsecured creditors at that time and, if we hold constant the probability of default, thereby transfers wealth to the preferred creditor from the nonpreferred creditors. Giving security for an antecedent debt has the same effect. At $T_{1}$ the remaining unsecured creditors will receive less than they would have received had the preferential transfer not been made. ${ }^{48}$ Both transactions are potentially vulnerable as preferences under Bankruptcy Code $\S 547,49$ which generally does not distinguish between

47 We suspect that even Professor Carlson would not equate D's payment to UC-1 instead of UC-2 with UC-1's theft of the property of UC-2. See David G. Carlson, Rationality, Accident, and Priority Under Article 9 of the Uniform Commercial Code, 71 Minn. L. Rev. 207, 245-46 (1986) (stating that a later-in-time secured financer who knowingly primes an earlier-in-time unperfected secured financer is a nalogous to a thief). Even if D had been insolvent at the time it paid UC-1, the transfer would be respected unless D intended to "hinder, delay, or defraud" creditors. See Unif. Fraudulent Transfer Act $\S 4(a)(1), 7$ A U.L.A. 652 (1985) ("UFTA"). Because payment of an antecedent debt is a transfer for reasonably equivalent value, it would not be avoidable under the "constructive" fraud provisions of the UFTA. See UFTA $\S \S 3(a),(b), 4(a)(2), 5(a), 7 A$ U.L.A. 650-57 (1985). However, the payment might be avoided as a preference under Bankruptcy Code $\S 547$. See infra text accompanying notes 49-50. We do not mean to suggest here that normative support for the respect the law gives to security interests can be gleaned from existing fraudulent transfer law. Instead, we mention current fraudulent transfer law to illustrate the radical nature of the notion that secured transactions are suspect on wealth transfer grounds-an observation that casts doubt on the hypothesis imbedded in much of the Efficiency Literature. We offer our normative case in Part II, infra.

48 Assume that $\mathrm{D}$ was insolvent at $\mathrm{T}_{0}$, with assets of $\$ 240$ and unsecured debt of $\$ 300$ (\$100 owed to UC-1 and $\$ 200$ owed to UC-2). As explained already, the distribution to UC- 1 and UC-2 would be $\$ 240$, or $80 \%$ of their claims $(\$ 240 / \$ 300=80 \%)$. Now assume that at $\mathrm{T}_{0} \mathrm{D}$ paid UC-1 in full ( $\left.\$ 100\right)$, leaving assets of $\$ 140$ and debt owed to UC-2 of $\$ 200$. The distribution to UC-2 would be $\$ 140$, or $70 \%$ (because $\$ 140 / \$ 200=70 \%$ ). The same result would obtain if at $\mathrm{T}_{0} \mathrm{D}$ secured UC-1's claim with property worth $\$ 100$.

4911 U.S.C. $\S 547$ (1988). 
payments and transfers as security. ${ }^{50}$ But, because the grant of a security interest does not necessarily deplete the assets available for use by the debtor, a preferential transfer of security may well have a less deleterious effect on the expected recovery of other creditors than would a preferential payment.

The foregoing suggests that, from the perspective of UC-2, the consequences of D's making a payment to UC-1 are indeterminate. The expected value of UC-2's recovery might increase; it might decrease. The same is true if D secures its debt to UC-1: One cannot ascertain the implications of the transaction for UC-2 a priori.

Now consider the consequences to existing creditors (UC-1 and UC-2) of D's selling an asset. ${ }^{51}$ Whether the expected return to creditors will increase or decrease depends on whether D makes more productive use of the cash received or of the asset sold. The grant of security for a new loan is quite similar to the sale of property; in both cases, $\mathrm{D}$ receives cash and parts with an asset. Of course, there are differences between a cash sale at $\mathrm{T}_{0}$, on one hand, and giving security to SP for a new loan at $\mathrm{T}_{0}$, on the other. One such difference arises from the possibility that at $T_{1}$ the unpaid and now undersecured SP may assert a deficiency claim that competes with the claims of UC-1 and UC-2 against a now insolvent D. Holding everything else constant, the secured transaction with SP reduces the expected return of the other creditors. In contrast, the cash seller to $\mathrm{D}$ is out of the picture at $\mathrm{T}_{1}$ and does not hold a competing claim in an insolvency proceeding.

But, once again, the distributive effects in insolvency are only part of the story. In the cash sale D loses the use of the asset sold, whereas with the secured loan D normally retains the use and possession of the collateral as well as the proceeds of the loan. D's retention of the use, possession, and control of collateral has value - value that is not available if a buyer carries the collateral away. This additional value typically is reflected in the difference between the amount of the secured loan (which is the measure of the secured creditor's property interest in the collateral) and the

50 See Bankruptcy Code $§ 547$ (b).

51 For ease of explication, the discussion in the text focuses on the cash sale of an asset. The discussion applies equally to the cash purchase of an asset and to noncash sales and purchases; that is, it applies generally to the parting with an interest in property in exchange for an interest in other property. 
(presumabiy greater) value of the collateral. Thus, unlike a seller, a debtor who grants a security interest enjoys more than the value represented by the cash it receives in the transaction. The debtor's retention of the additional value represented by the continued right to use, possess, and control the collateral may reduce the risk of default, perhaps enough to offset the reduction in the expected recovery of creditors' claims that otherwise would occur. ${ }^{52}$

Cash payments, purchases, and sales, like secured loans, can result in wealth transfers from the unsecured creditors of a buyer or seller and can expose the unsecured creditors to additional risk, although these transactions do not necessarily do so. ${ }^{53}$ Thus, one cannot develop a plausible hypothesis for questioning the utility or equity of security interests on distributional grounds involving transfers of wealth, such as the reduction of the pool of assets remaining for unsecured creditors or the present value of remaining unsecured claims, unless one also questions, on similar grounds, other transactions such as payments, sales, and purchases. Consequently, one cannot view the creation of effective security interests with suspicion on those grounds unless one also questions the general effectiveness of these transactions. ${ }^{54}$

52 In some cases, the value attributable to the debtor's continued use, possession, and control may be negative. For example, the debtor's continued use may enable the debtor to stay in business longer, and thereby incur more debt and losses, when the value of the enterprise would be greater had operations ceased earlier. Although we suspect that such cases are uncommon, the point remains that, without additional information, one cannot determine the relative effect on unsecured creditors of an outright disposition of property or the use of the same property as collateral.

53 Many creditors recognize the risks that certain transactions may present and negotiate for covenants that restrict their debtors' activities. Giving security represents only one of many classes of transactions that could increase risks for unsecured creditors and that are the subject of such covenants. For example, covenants frequently restrict debtors' right to borrow (whether on a secured or unsecured basis), to sell substantial portions of their assets, to pay dividends and make other distributions on equity, and to merge with other entities. See generally Committee on Devs. in Business Fin. of the Section of Corp., Banking and Business Law, Am. Bar Assn., Term Loan Handbook 162-77 (John J. McCann ed., 1983) (discussing covenants concerning mergers and consolidations, sales of stock of subsidiaries, maintaining subsidiaries, leasing, liens, financial condition, distributions and investments, and transactions with affiliates).

54 In Part III we develop the converse of this proposition: the considerations that lead to the general validation of payments, sales, and purchases also support making secured transactions effective. 


\section{Why Do Debtors Sometimes Give Security? Is Secured Credit Efficient?}

The eifficiency of secured credit is but one of at least three central questions that the Efficiency Literature addresses: First, why do some debtors give security interests under the current legal regime? Second, does the granting of security under current law promote efficiency? ${ }^{55}$ Third, should the law facilitate (indeed, as put by Jackson and Kronman, should the law "permit") secured transactions? Although answers to each question may inform answers to the others, each question raises distinct issues. ${ }^{56}$

Answers to the first question, why some debtors actually give security, seem rather easy to us. Many borrowers can obtain the credit they desire only if they give collateral. Familiar examples are the secured purchase-money financing of commercial and residential real estate, business equipment, aircraft, and consumer goods such as automobiles, boats, and appliances. Much nonpurchase-money financing also is made available to some borrowers only on a secured basis. Working-capital loans often are secured by a "borrowing base" consisting of inventory and receivables; ${ }^{57}$ lines of credit and committed credit facilities for small busi-

55 Some contributors to the Efficiency Literature appear to be offering advice to prospective borrowers as to when it would or would not be in their interests to give security. See, e.g., Picker, supra note 10, at 677; Triantis, supra note 10, at 257-58. These efforts appropriately could be classified in our taxonomy as raising the first question. We believe, however, that they probably are classified more accurately as attempts to answer the second question: Is secured credit efficient?

56 Schwartz' most recent contribution is sui generis. He proposes a detailed priority scheme, the centerpiece of which is that the "initial financer" (which he defines as "the first creditor that made a substantial loan that would be outstanding for a nontrivial time period") ordinarily would rank first, whether secured or not. Schwartz, supra note 6, at 247. For our brief critique of Schwartz' proposal, see Honnold et al., supra note 6, at 56264. In our critique we suggest that the proposal depends on an erroneous assumption concerning the behavior of lenders (that they are not discouraged from lending by the knowledge that the transaction would violate the borrower's negative covenant in another lending contract) and an erroneous assumption concerning legal doctrine (that such a lender need not fear tort liability when the debtor had already made up its mind to violate the covenant). Id. at 564.

57 Honnold et al., supra note 6, at 77 ("The current jargon used to refer to transactions in which the lender relies heavily on the value of its collateral is asset based financing. In a typical arrangement a borrower would be required to maintain at all times a borrowing base value of inventory and qualifying (not in default) receivables that is at least equal to the outstanding loan balance. Normally, the borrowing base would be a percentage (say, 
nesses typically are secured by "all assets" of the borrower. ${ }^{58}$ And many large extensions of credit to securities market participants are secured, as well. ${ }^{59}$ These illustrative patterns involve borrowers who desire credit and find unsecured credit unavailable at a rate competitive with the rate for secured credit (or unavailable altogether, under the circumstances). These borrowers perceive it to be in their interest to borrow, and secured borrowing represents their best (or only) alternative for borrowing. Consequently, they give security.

Explaining why some debtors give security under current law, under prevailing market conditions, and in particular circumstances does not prove that secured credit necessarily is socially useful. The second question raised in the Efficiency Literature-Is secured credit efficient?-does implicate social welfare. Schwartz and other contributors to the Efficiency Literature have compared the impact (on a debtor's unsecured creditors) of the debtor's obtaining secured credit only with the corresponding impact of the debtor's obtaining unsecured credit. As a result, these commentators have puzzled over why unsecured creditors do not charge a risk premium that of fsets the presumed reductions in risk premiums resulting from giving security to the new creditor. But, as explained above, because many borrowers cannot obtain credit without giving security, ${ }^{60}$ and because the otherwise unavailable extension of credit to a debtor may result in benefits to the debtor

$60 \%$ ) of the book value of inventory plus a percentage (say, $75 \%$ ) of the face amount of receivables.").

58 See Scott, supra note 10, at 940 (finding that "seventy-eight percent of the [sample of] loans to firms with assets of $\$ 50,000$ to $\$ 250,000$ were secured").

59 For example, government securities dealers typically must borrow substantial sums during each business day in order to finance securities received by them (actually, received by their "clearing banks" on their behalf) during that ciay. These borrowings typically take the form of overdrafts, which are secured by the securities received as well as other securities. The dealers must borrow additional funds to reduce these overdraft borrowings at the end of each business day. Many of these overnight borrowings are structured as "repos." See Marcia Stigum, The Repo and Reverse Markets 25-26, 57 (1989). Although not denominated secured loans, repos clearly are the functional equivalent. Their legal characterization for private law purposes - as either outright sales and resales or de facto secured loans-is unclear. See, e.g., Elizabeth M. Osenton, Comment, The Need for a Uniform Classification of Repurchase Agreements: Reconciling Investor Protection with Economic Reality, 36 Am. U. L. Rev. 669, 678-81 (1987).

60 See supra Part I.B. 
and its creditors (including its unsecured creditors), ${ }^{61}$ a potential solution to the puzzle appears.

We have argued that the extent to which secured transactions promote efficiency (or otherwise promote social welfare) is an empirical question, not susceptible of a definitive answer. Certainly, one cannot answer the question by investigating only the effects of secured credit given to debtors who have failed. Given this uncertainty, we have no difficulty answering the third question - Should the law facilitate (or permit) secured transactions?in the affirmative. ${ }^{62}$ In fact, we wonder whether it is worthwhile to ask and attempt to answer this question, at least as it has been asked in the Efficiency Literature.

Sound methodology requires care and judgment in the selection of hypotheses. Is there any basis to suspect that the law should not facilitate secured transactions? We doubt it. To ask the question "Should the law prohibit secured transactions?" as a heuristic procedure can lead to a fuller understanding of both the role secured credit plays in the contemporary economy and its specific effects upon unsecured creditors and debtors. Yet one gleans from some components of the Efficiency Literature that the inability to demonstrate conclusively the efficiency of secured transactions raises public policy concerns serious enough to call into question whether the law should honor and respect the creation of security interests. $^{63}$ Can anyone take seriously the claim that the law should prohibit or deny effectiveness to voluntary transfers of property interests (or any other voluntary acts by natural or legal persons) solely because the efficiency of the act is unproven or doubtful? ${ }^{64}$ Would anyone take seriously the claim that the law should prohibit payments to creditors or sales or purchases of assets, the efficiency of which is indeterminate? We think not.

61 See supra Part I.B.

62 For purposes of this discussion, we assume that the facilitation and effectiveness of security interests under Article 9 would be coupled with the general respect afforded security interests under the Bankruptcy Code. We address in more detail the relationship between security interests and bankruptcy policy in Part III, infra.

63 See, e.g., Jackson \& Kronman, supra note 10, at 1146 ("Why does the law permit secured financing in the first place?").

6t In Part 11.A, infra, we consider the efficiency and utility of transferability of property. 
We suspect that the contributors to the Efficiency Literature agree with us. Although the Efficiency Literature often questions the efficiency of secured credit in a manner consistent with normative arguments, the literature, fairly read, attempts to provide a positive analysis that explains the efficiency of secured credit. No one has called for abolition. Nor has any contributor to the Efinciency Literature suggested that Article 9 be amended to make the creation of effective security interests more difficult or expensive.

\section{E. Sympathetic Legal Studies}

We must take note of another group of sincere skeptics, whose concerns are more subtle but nonetheless identifiable - the adherents to a persistent but until now unnamed school of legal thought on debtor-creditor law, which we call Sympathetic Legal Studies ("SLS"). ${ }^{65}$ These adherents ("Symps") seem troubled primarily by the fact that secured creditors appear to recover a larger portion of their claims in bankruptcy than do unsecured creditors. To the Symps, this seems unfair. The Symps also are uneasy about the apparent power and influence that secured creditors may wield over a debtor's fortunes, both in and out of bankruptcy. The Symps' sympathies lie along a clearly defined food chain. They place insolvent debtors who cannot satisfy their obligations at the top of the chain. At the bottom, the Symps place fully secured creditors. Then they arrange unsecured and less-secured creditors somewhere in the middle.

Failing to appreciate that maintaining the status quo can be as profound as proposing change, the Symps frequently lament the plight of debtors and unsecured creditors but rarely propose concrete law reforms (especially those that relate to nonbankruptcy law). For example, the Symps have sounded no alarms about the favorable treatment afforded to transferees who buy a debtor's assets or receive payments from debtors, an issue discussed in Part I.C; apparently the Symps are content to rely on the law of fraudulent transfer and the prospects for avoidance of preferences in

65 We realize that SLS is not necessarily a coherent, monolithic, and well-defined "school of thought," and we do not claim that any natural person, living or dead, actually subscribes to each of the tenets that we attribute to SLS. Rather, we exaggerate the views of an aggregation of commentators who have expressed skepticism from time to time. 
bankruptcy. Nor is there a clamor for treating as fraudulent transfers all non-pro-rata transfers made by solvent debtors in exchange for reasonably equivalent value.

SLS, like the Efficiency Literature, does not embrace the outright abolition of secured transactions, which are but one species of transfer for reasonably equivalent value (transfers of security interests, of course, necessarily are for precisely equivalent value). ${ }^{66}$ As explained above ${ }^{67}$ it is no surprise that no one seems to take seriously the prospect that security interests actually might be abolished. But, assuming that secured transactions are not outlawed, how do the Symps manifest their apparent dissatisfaction with the respect that the law generally affords secured transactions? We have observed Symps taking positions that may well reflect the wish that security interests were more difficult, more time consuming, and more expensive to create, and that security interests, once created, were less reliable. What genuinely may concern many Symps about the pending revision of Article 9 is the prospect of a world in which slip-ups by secured creditors will be so rare that debtors in bankruptcy seldom will be positioned to upset the agreement of the parties by avoiding unperfected security interests. Reducing the opportunities to hold secured parties hostage means there may be less cash available for debtors to continue operating their businesses, pay their counsel, and make distributions to their unsecured creditors. On the other hand, the more difficult it is to figure out how to perfect or where to file, the more likely it is that slip-ups will occur. Thus the Symps' "symple" solution (although few Symps may be so bold as to articulate this position frankly): Keep it cumbersome, encourage the slip-ups, and redistribute the secured creditors' property interests as the slip-ups (invariably) arise.

Given that security interests will not be abolished, the Symps should come forward with a principled basis for casting a cloud of doubt or suspicion about security interests generally. If they really wish to argue that the creation of security interests should be more difficult, time consuming, expensive, and risky, then they must

66 The statement in the text assumes a legal regime, like that of Article 9, that prohibits strict foreclosure without the debtor's consent.

67 See supra text accompanying notes 63-64. 
explain why. And if the burdens under current law are too light for the effective creation of secured credit, perhaps the Symps also should explain why other methods of exchange and wealth transfer-paying, buying, and selling, for example — should not be made more expensive and cumbersome. As we have explained, those transfers also can disadvantage unsecured creditors.

We suspect that there lies at the core of the Symps' concerns about secured credit the same fundamental misconception that has afflicted the Efficiency Literature-the myth that secured credit somehow has a necessarily adverse distributional effect on unsecured creditors. We have shown that there is no basis for that hackneyed story once one realizes that much credit would not be extended at all in the absence of security. Thus, the difficulty that the Symps confront is the same reality that thwarts the Efficiency Literature. The case against secured transactions must be an empirical one, which cannot be grounded solely on the distributional consequences of secured credit when the debtor is insolvent. That case has yet to be made.

In Part II we identify a normative anchor for the respect that the law affords the creation of security interests. While advancing our normative claim and rejecting the myth of adverse distributional consequences, however, we hasten to acknowledge that sound reasons may justify the imposition of a variety of formalities, restrictions, and conditions on the effectiveness of both contracts and transfers of property interests. Security interests, in particular, may possess characteristics that warrant some special legal rules. We examine these characteristics and a range of plausible responses to them in Part II.B.

\section{Security Interests as Property}

A. Free and Effective Alienability of Property and Freedom of Contract: A Normative Theory of Secured Transactions

Our normative theory of security interests is grounded upon the normative theories that justify the institution of private property. The right to own private property is the bedrock of capitalism and 
an essential component of a market economy, ${ }^{68}$ Consider four elements of the ownership of property:

(i) the right to use an asset (usus), (ii) the right to capture benefits from that asset (usus fructus), (iii) the right to change its form and substance (abusus), and (iv) the right to transfer all or some of the rights specified under (i), (ii), and (iii) to others at a mutually agreed upon price. ${ }^{69}$

Implicit in these elements is an owner's right to exclude others from exercising ownership rights over the owner's property. ${ }^{70}$ Scholars have given several accounts of the social benefits of private property, including the promotion of economic efficiency, the enhancement of political freedom and liberty, the contribution to an owner's sense of "self," and the encouragement of innovation. ${ }^{71}$ Although the desirability and general outline of a legal regime regulating the ownership of private property in a free-market economy are not particularly controversial, the details of that regulation may give rise to substantial disagreement.

68 When used in its broadest sense, "property" includes the general regulation of relations among parties and encompasses much more (e.g., the right to vote, speak, and the like) than we address here. We do not use the term in such a broad sense.

69 Svetozar Pejovich, The Economics of Property Rights: Towards a Theory of Comparative Systems 28 (1990).

70 Harold Demsetz, Toward a Theory of Property Rights, in The Economics of Legal Relationships: Readings in the Theory of Property Rights 29-30 (Henry G. Manne ed., 1975).

71 See, e.g., Milton Friedman, Capitalism and Freedom 8 (1962) (arguing that freedom in economic arrangement is "itself a component of freedom broadly understood, so economic freedom is an end in itself," and also is an "indispensable means toward the achievement of political freedom"); Lawrence C. Becker, The Moral Basis of Property Rights, in Property: Nomos XXII, at 187, 212 (J. Roland Pennock \& John W. Chapman eds., 1980); Demsetz, supra note 70; J. Roland Pennock, Thoughts on the Right to Private Property, in Property: Nomos XXII, supra, at 171, 178; Margaret J. Radin, Property and Personhood, 34 Stan. L. Rev. 957, 992 (1982) (arguing that private property promotes political freedom by permitting individuals "some realm shut off from the interference of others"); Frederick G. Whelan, Property as Artifice: Hume and Blackstone, in Property: Nomos XXII, supra, at 101. On the same subject, David Hume wrote:

[P]ersons and possessions must of ten be very ill adjusted. . . To . . . allow every man to seize by violence what he judges to be fit for him, wou'd destroy society; and therefore the rules of justice seek some medium betwixt a rigid stability, and this changeable and uncertain adjustment. But there is no medium better than that obvious one, that possession and property shou'd always be stable, except when the proprietor consents to bestow them on some other person.

David Hume, A Treatise of Human Nature 514 (L.A. Selby-Bigge ed., 1965). 
According to a well-known economic account, private property promotes efficiency by providing incentives for the allocation of property to those who place the highest value on its use. ${ }^{72}$ This explanation draws primarily on the interaction of the transferability of property, the enforceability of contractual rights, and the profit-maximizing behavior of individuals and firms. Private property also can promote efficiency in other ways, as by curing the "common pool" problem (or the "tragedy of the commons").73

A central feature of the economic account of property is the transferability - free alienability - of property rights, without which resources could not find their way to users who value them more. Nevertheless, some restrictions on alienability actually may promote efficiency. In her study of inalienability, ${ }^{74}$ Susan RoseAckerman explained that "the familiar problems of externality control[,] . . . imperfect information, 'prisoner's dilemmas,' free rider problems, and the cost of administering alternative policies" each may justify appropriate restraints on alienation. ${ }^{75}$ And some restraints may be warranted on normative grounds unrelated to economic efficiency. ${ }^{76}$

In our legal culture the principle of freedom of contract is closely interrelated with private ownership and free alienation of property. Each concept manifests respect for the autonomy of the persons

72 See Charles J. Goetz, Law and Economics 52 (1984); R.H. Coase, The Problem of Social Cost, 3 J.L. \& Econ. 1 (1960).

${ }^{73}$ For example, if a pasture is open to all (because it is not owned by anyone or it is owned communally), cattle herders will graze increasing numbers of cattie without regard for the resulting overgrazing and destruction of the pasture. This result, an externality, reflects the fact that the full cost or effect of a decision is not borne by the decisionmakers. (Here, none of the herders has to pay anything for grazing additional cattle.) A single owner of the pasture, however, can internalize the costs of overgrazing (an externality) by excluding others from using the pasture; using the pasture for a more profitable enterprise. such as growing crops; or selling or leasing the pasture. See Alan E. Friedman, The Economics of the Common Pool: Property Rights in Exhaustible Resources, 18 UCLA L. Rev. 855 (1971); Garret Hardin, Tragedy of the Commons, in Economic Foundations of Property Law 2 (Bruce A. Ackerman ed., 1975).

74 Susan Rose-Ackerman, Inalienability and the Theory of Property Rights, 85 Colum. L. Rev. 931 (1985).

75 Id. at 932

76 See David G. Carlson, Is Fraudulent Conveyance Law Efficient?, 9 Cardozo L. Rev. 643 (1987) (disputing claim that fraudulent conveyance law is efficient while justifying it on philosophical grounds). The most significant restraints on alienation affecting security interests are fraudulent transfer law and its offshoots, public notice requirements under both Article 9 and real estate law. We examine these familiar restraints in Part II.B. 
concerned. ${ }^{77}$ Yet this "freedom of contract" abstraction that so dominated classical contract law doubtless does not and never did exist in a pure form in the real world. ${ }^{78}$ Although the central attribute of an enforceable contract is the right of a party to call upon the state's coercive power to provide a remedy, examples abound both of contracts that the courts will not enforce ${ }^{79}$ and of challenges to the theoretical bases for contract law. ${ }^{80}$ These disagreements as to why contracts are enforced and as to the costs and benefits and theoretical underpinnings of contract law have consequences primarily at the margin. They do not call in to question the ultimate conclusion that the law should continue to enforce a vast array of contracts entered into by a wide swath of parties.

We embrace the baseline principles that underlie current law insofar as it generally respects the free and effective alienation of property rights and the ability of parties to enter into enforceable contracts. We believe that these principles reflect widely shared normative views that favor party autonomy concerning both property and contract. We need not undertake, here, a defense of these

77 See, e.g., Tamar Frankel, The Legal Infrastructure of Markets: The Role of Contract and Property Law, 73 B.U. L. Rev. 389, 393 (1993) ("[T]he values underlying both contract and property law recognize the parties' freedom, but differ in the extent and nature of that freedom.") (footnote omitted). The U.C.C. generally embraces freedom of contract. See U.C.C. $\S 1-102(3) \& \mathrm{cmt} .2$.

78 See, e.g., Jay M. Feinman, Critical Approaches to Contract Law, 30 UCLA L. Rev. 829, 830-47 (1983) (comparing nineteenth- and early-twentieth-century "classical contract law" with more recent theories of contract law); see also Betty Mensch, Freedom of Contract as Ideology, 33 Stan. L. Rev. 753 (1981) (reviewing P.S. Atiyah, The Rise and Fall of Freedom of Contract (1979)).

79 See, e.g., U.C.C. $\$ 2-302$ (stating that court may refuse to enforce unconscionable contract or clause); Restatement (Second) of Contracts $\S 178$ (1979) (stating that term of contract may be unenforceable on grounds of public policy); see also Eric A. Posner, Contract Law in the Welfare State: A Defense of the Unconscionability Doctrine, Usury Laws, and Related Limitations on the Freedom to Contract 52 (forthcoming 1995) (on file with the Virginia Law Review Association) ("[U]sury laws, the unconscionability doctrine, and similar laws restricting freedom of contract are best understood as legal mechanisms for restricting the extension of credit to high-risk borrowers, particularly the poor; and ... this policy is broadly consistent with the goal of maintaining a welfare system within a free market.").

so See, e.g., Feinman, supra note 78; Duncan Kennedy \& Frank Michelman, Are Property and Contract Efficient?, 8 Hofstra L. Rev. 711, 714 (1980) (arguing that the efficiency of private property and free contract cannot be deduced solely from an assumption of rational maximizing behavior). 
principles. Instead, we accept them as sound and consider their implications for the law of secured transactions. ${ }^{81}$

It seems clear enough that security interests, under Article 9 and real estate law alike, are interests in property. ${ }^{82}$ The legal regime for security interests reflects property law functionally as well as doctrinally. ${ }^{83}$ We believe it follows that the law should honor the transfer or retention of security interests on the same normative grounds on which it respects the alienation of property generally. ${ }^{84}$

S1 We do not assert that the mere existence of concepts called "property" or "contract" or the fact that certain behavior typically occurs proves our normative claim. Rather, we base our claim on the widely shared normative support for party autonomy in these realms. Of course, if party autonomy principles of property and contract law were discredited or radically altered, then we would wish to reconsider secured transactions in that light. But that is another project.

82 See, e.g., U.C.C. §1-201(37) (" 'Security interest' means an interest in personal property ...."); Restatement (Third) of Property-Security (Mortgages) § 1.1 (Tentative Draft Mar. 22, 1991) ("A mortgage is a conveyance of an interest in real property as security for an obligation."); see also Bankruptcy Code $\S 361$ ("When adequate protection is required [by this Code] of an interest of an entity in property, such adequate protection may be provided by ... granting such other relief ... as will result in the realization by such entity of the indubitable equivalent of such entity's interest in such property."). But see Lynn M. LoPucki \& Elizabeth Warren, Secured Credit: A Functional Approach (forthcoming 1994) (unpublished manuscript, on file with the Virginia Law Review Association). Adopting a heuristic that they call "functional," Professors LoPucki and Warren scrupulously eschew any acknowledgement that security interests are property interests. This approach is likely to obscure both the doctrine imbedded in current law and many of the functions of security.

83 A security interest affords the secured party an amalgam of rights that traditionally have constituted "property": (i) the right to possess and use the collateral (albeit on certain conditions and for a limited purpose), see U.C.C. § 9-503 (right to take possession); id. § 9502 (right to collect); id. $\S 9-504$ (right to dispose); (ii) the right to capture benefits from the collateral, see id. § 9-306 (security interest continues in proceeds); id. § 9-502(1) (right to take control of proceeds); (iii) the right to exclude others, including the debtor and third parties, from exercising certain rights with respect to the collateral, see, e.g., id. §§ 9-301, -312 (right to priority over third parties); and (iv) the right to transfer the foregoing rights to others at a mutually agreed upon price, see id. $\$ 9-405$ (right to assign a security interest). These rights are not merely incidental to the security interest; they are its essence.

More generally, it is fair to observe that the law of debtors and creditors is a subset of property law, with a handful of civil procedure thrown in the pot. Debtor-creditor law addresses such questions as: How does a creditor convert an intangible right to payment into an interest in a debtor's property? How are priorities assigned to claims and resulting property interests of various creditors?

84 Professor Bowers comes close to making this point. He argues that debtors are likely to make optimal distributional decisions, and he criticizes Professor Schwartz for ignoring the "legal" and "bankruptcy" view of security devices as "property." See Bowers, supra note 10 , at 58-60, 59 n.85. 
Because security interests are property, any general theory of the law of secured transactions must emanate from theories of property law. The challenges posed by the Efficiency Literature and SLS derive primarily from the distributive effects of secured credit on unsecured creditors of a debtor who has become insolvent. We explained in Part I that, insofar as any distributive effects of wealth transfers and any adverse effects on existing and future unsecured creditors are concerned, the transfer of a security interest does not differ fundamentally from other transfers of a property interest in exchange for equivalent value. Thus, to carry the day, those who question secured transactions must attack the generally applicable treatment of party autonomy in property and contract law or must explain why secured transactions differ from other transactions that the law respects. ${ }^{85}$

The legal regime's respect for transfers of property interests is not premised on the belief that each owner's alienation of an interest in its property necessarily and universally produces a normatively desirable result. Rather, it is based in large part on the idea that respecting an owner's liberty to freely alienate its property generally promotes social welfare. ${ }^{86}$ This is much more than a point about "burden of proof" in proposing law reforms, reflected by the maxim "If it ain't broke, don't fix it." To the extent that the existing law governing secured transactions reflects the larger, widely shared social values of free alienability and party autonomy, that law presumptively is sound.

The positive value of permitting debtors to give security freely and effectively suggests two important rules of thumb to be fol-

85 To make the point in a slightly different context: one who advocates the social benefits of credit generally but doubts that the benefits arise in the case of borrowers whose names begin with $\mathrm{E}, \mathrm{Q}$, and $\mathrm{T}$ must show why credit extended to those debtors differs from other credit. Douglas Baird and Thomas Jackson issued a very similar challenge with respect to a specific aspect of secured transactions: "At the very leasi ... those who question the usefulness of a filing requirement in the case of leases should explain why there should be a filing requirement in the case of secured transactions that are identical from the point of view of third parties." Douglas G. Baird \& Thomas H. Jackson, Possession and Ownership: An Examination of the Scope of Article 9, 35 Stan. L. Rev. 175, 189 n.4ó (1983).

So This is not to say, of course, that the law does not or should not place any limitations on alienation. The social costs of any particular class of alienation of a particular type of property interest by or to a particular class of transferor or transferee may or may not outweigh the accompanying social benefits. 
lowed in the process of revising Article 9. First, the drafters should purge Article 9 of obstacles to the creation of effective security interests. ${ }^{87}$ Because there is nothing generally unsound or suspect about the creation of effective security interests, formalistic requirements that upset the intentions of the parties and prove to be traps for the unwary should be eliminated. Second, the scope of Article 9 should be expanded. Many of the common-law rules governing the creation of security interests in personal property are uncertain and cumbersome. Insofar as the creation of security interests is easier, less costly, and more certain under Article 9 than under common-law rules, expansion of the statute is likely to serve the overarching goal of effectuating the will of the parties. The drafters should add limitations and restrictions only when they are demonstrably warranted in particular circumstances. Moreover, the presumption against interference with party autonomy should extend to existing impediments (e.g., public notice requirements) as well as to proposed new ones.

\section{B. Limitations on the Creation of Effective Security Interests}

The preceding Section argues that those who would question, on wealth-distribution grounds, the wisdom of generally respecting security interests bear a heavy burden. They must attack directly the respect that the law generally affords the free and effective alienability of property rights or (more plausibly) explain why, based on distributional concerns, the law should treat security interests differently from other transfers of property interests. No one has met that burden. We doubt that anyone will.

For security interests, as with other transfers of interests in property, the law does and should make appropriate exceptions to the principle that one may alienate property freely and effectively. This Section considers the most important exceptions: fraudulent transfer law and public notice requirements for nonpossessory security interests. ${ }^{88}$ These exceptions recognize that the creation

87 Professors Buckley and Triantis also argue explicitly for this approach. See Buckley, supra note 10; Triantis, supra note 10 , at 226.

ss Fraudulent transfer law and public notice (perfection) requirements turn on concern for other creditors and do not affect the validity of security interests between the debtor and the secured party. In that respect, these requirements are not so much restraints on alienation itself but instead conditions to alienation that are effective against third parties 
and enforcement of security interests give rise to externalities other than potentially adverse distributional consequences for unsecured creditors. $^{89}$

Fraudulent transfer law and public notice requirements for nonpossessory security interests are linked historically. Many early efforts to create nonpossessory security interests followed the structure of the real estate mortgage. They were documented as a sale of the collateral, subject to defeasance upon discharge of the secured obligation. ${ }^{90}$ Creditors who obtained judicial liens on property subject to a chattel mortgage challenged these transactions under fraudulent transfer law. Their challenge, often successful, was facilitated by the widely held view that the failure to transfer possession of goods to the buyer constituted, at a minimum, a "badge of fraud." In Inasmuch as the "seller" (debtor) under a chattel mortgage typically did not transfer possession of

The doctrine of good faith purchase also impinges on the effectiveness of security interests. See, e.g., U.C.C. § 9-307(1) (providing that buyer in ordinary course of business takes free of security interest created by the buyer's seller); id. § 9-309 (providing that Article 9 does not limit rights of purchasers entitled to take free of adverse claims under Articles 3, 7, and 8). We discuss the avoidance of certain security interests in bankruptcy in Part III, infra.

89 This Section also addresses briefly certain other restrictions on secured credit, such as those intended to provide protection to consumers.

90 For example, the conveyancing document in Clow v. Woods, 5 Serg. \& Rawle 275 (Pa. 1819), provided that the debtor "hath bargained and sold, and by these presents doth bargain and sell," collateral to the secured parties, and that if the debtor does "well and truly pay or cause to be paid the debt aforesaid; . . . then this present indenture and everything herein contained shall cease, determine and be void." Id. at 277.

91 The idea that the failure to transfer possession of goods upon a purported conveyance constitutes one of the "badges of fraud" goes back to Elizabethan England. See Twyne's Case, 3 Coke 80b, 76 Eng. Rep. 809 (K.B. 1601). Twyne construed the Statute of Fraudulent Conveyances, 13 Eliz. ch. 5 (Eng. 1570), which invalidated conveyances made for the purpose of hindering, delaying, or defrauding creditors.

The Statute of Fraudulent Conveyances was either received into the common law or reenacted by most jurisdictions in the United States. Although it was but one of six badges of fraud present in Twyne, retention of possession after sale became sufficient in some jurisdictions for a court to hold as a matter of law that the sale constituted a fraud on creditors. See, e.g., Sturtevant v. Ballard, 9 Johns. 337, 344 (N.Y. Sup. Ct. 1812) ("[A] voluntary sale of chattels, with an agreement ... that the vendor may keep possession, is, except in special cases, and for special reasons, to be shown to, and approved of by, the court, fraudulent and void, as against creditors."). In other jurisdictions, the fact of the seller's retention of possession was sufficient to permit a jury to find that a fraud had occurred as a matter of fact. See, e.g., Highley v. American Exch. Nat'l Bank, 57 N.E. 436 (IIl. 1900). Likewise, the UFTA adopts a "fraud-in-fact" approach. See UFTA § 4(b)(2), 7A U.L.A. 653 (1984) (providing that among the factors that may be considered in determining whether a transfer is made with "actual intent to hinder, delay, or defraud any 
the collateral to the secured party, courts had readily available doctrinal support for finding that nonpossessory security interests could be avoided by other creditors.

To one not schooled in the history of personal property security, the connection between retention of possession and fraud is not likely to be self-evident. Consider the observation of the Star Chamber in its seminal opinion in Twyne's Case:"92 "The donor continued in possession [of the goods] and used them as his own; and by reason thereof he traded and trafficked with others, and defrauded and deceived them."93 This notion-that the debtor's "ostensible ownership" of goods subject to a nonpossessory security interest may mislead other creditors into thinking that the goods are unencumbered-underlies a good deal of the caselaw and commentary written during the first half of this century ${ }^{94}$ and has found favor with two prominent Article 9 scholars. ${ }^{95}$ One common explanation of and justification for the Article 9 filing system is as a solution to the "ostensible ownership problem."96 Under this view, the publicly available information revealed in a financing statement dispels any mistaken belief that a competing creditor might have concerning the status of the debtor's interest in the collateral.

For reasons one of us has explained elsewhere, ${ }^{97}$ we think "ostensible ownership" per se is not a significant problem. Even if it was so in 1603 or 1811, when separation of ownership from possession may have been so unusual as to catch third parties by surprise, it is not likely to be so today, when chattel leases and nonpossessory security interests abound. In fact, a closer look at Twyne-as well as at a number of cases relying upon it for the

creditor" is whether "the debtor retained possession or control of the property transferred after the transfer").

92 Twyne, 3 Coke at 80b, 76 Eng. Rep. at 809.

93 Id. at 81a, 76 Eng. Rep. at 812-13.

94 See, e.g., 1 Garrard Glenn, Fraudulent Conveyances and Preferences $\S \S 346-348$, at 605-07 (rev. ed. 1940).

95 See Baird \& Jackson, supra note 85, at 178.

96 Id. at 183.

97 See Charles W. Mooney, Jr., The Mystery and Myth of "Ostensible Ownership" and Article 9 Filing: A Critique of Proposals To Extend Filing Requirements to Leases, 39 Ala. L. Rev. 683, 738-43 (1988) (explaining that possession does not connote ownership and that possession frequently is not readily observable by interested persons (i.e., is not "ostensible")). 
proposition that retention of possession is fraudulent because it creates the deceiving appearance that the seller/debtor owns unencumbered goods-reveals that the pre-Article 9 courts were concerned primarily with a different type of fraud: the potential for the transaction to be used for dishonest purposes. In Twyne itself, the aggrieved creditor ("C") did not extend credit in mistaken reliance upon the debtor's (Pierce's) ostensible ownership. "98 Some of the other badges of fraud suggest that the court simply did not believe that the purported conveyance-a transfer of all Pierce's property to Twyne in satisfaction of an antecedent debt-actually had taken place. The transfer in question occurred "pending [C's] writ" and was "general, without exception of [Pierce's] apparel, or any thing of necessity." 99 Consider the scenario: Just when one of Pierce's creditors was about to enforce its claim, Pierce decided to satisfy his debt to Twyne by conveying everything he owned, even life's necessities. And if that isn't suspicious enough, it turns out that Pierce had cut a secret deal with Twyne, under which Twyne agreed to let Pierce use the property that Twyne purportedly had taken in satisfaction of his claim. In short, Pierce retained all the benefits of ownership but insulated the property from the reach of his creditors. The fraud lies in the fact that the conveyance was not what it purported to be. The purported conveyance was a sham, designed to prevent $\mathrm{C}$ from satisfying its claim against Pierce. ${ }^{100}$

Just as public notice of a transaction (typically, a filed financing statement) has been thought to ameliorate an ostensible ownership problem, so public notice has been thought to reduce the likelihood that the debtor and a third party will conspire to defeat the claims of a creditor by asserting that the third party took a security interest when, in fact, the third party did not. ${ }^{101}$ Hence, common-

98 The conveyance was made pending C's writ; C would not have been entitied to a writ unless $C$ already had a claim against Pierce. Regardless of whether $C$ became a creditor before Pierce acquired the property in question or during Pierce's ownership, $\mathrm{C}$ would not have been deceived into extending credit in mistaken reliance on the state of Pierce's title.

99 Twyne, 3 Coke at 81a, 76 Eng. Rep. at 812-13.

100 See also Clow v. Woods, 5 Serg. \& Rawle 275, 282 (Pa. 1819) ("I do not suppose the parties [to a nonpossessory chattel mortgage] had in fact a fraudulent view, but as such a transaction might be turned to a dishonest use, it was their duty, as far as in their power, to secure the public against it.").

101 Note:

The filing made in a public office ensures the veracity of the timing and the existence of a security interest by eliminating the possibility, which might exist under a "first- 
law and statutory rules conditioned the effectiveness of a security interest against third parties on the secured party's having given public notice of its security interest.

For the most part, courts and commentators have not distinguished between "ostensible ownership" and "sham transaction" fraud. Because these frauds are not identical, one should not expect an identity in the types of public notice that would be an effective response to each. For example, if ostensible ownership is a real problem (which we doubt), then a financing statement would have little value unless it enables competing creditors to disabuse themselves of the mistaken belief that the debtor owns property in its possession free and clear, that is, unless the statement could be found by potential searchers of the public record. This observation suggests that courts should exact strict compliance with the statutory provisions governing the place of filing and the name of the debtor, and that the statute should contain stringent requirements for correcting the public record as operative facts change (e.g., if the debtor changes its name or the collateral moves to another jurisdiction). On the other hand, if the purpose of filing is to give credence to the assertion that the alleged secured transaction actually occurred, then there is no reason to insist on the purity of the public record. This "anti-sham" approach would validate a financing statement even though the financing statement could not be found in the public records and thus would be ineffective to cure any ostensible ownership problem. ${ }^{102}$

Notwithstanding our skepticism concerning the "ostensible ownership" problem, we are inclined to favor a filing system that pro-

to-attach" rule, that a debtor and a secured party could conspire to claim that a security interest was created earlier than it actually was. ...

Notice filing does not actually evidence the creation of a security interest.

However, because the time of filing generally controls priorities, there is little risk that collusion concerning the time of creation will affect priorities.

Mooney, supra note 97 , at 752 \& n.264.

102 For example, this "sham transaction" approach would validate a financing statement containing a serious typographical error in the debtor's name, such as "Looney" for "Mooney" or "Farris" for "Harris." Article 9 currently rejects such an approach in favor of one that appears to have been fashioned with ostensible ownership in mind. See U.C.C. $\$ 9-402(8)$ (providing that financing statement that substantially complies with the statutory requirements is effective even if it contains minor errors that are not seriously misleading). 
vides public notice of the kind that enables third parties to discover whether particular property may be encumbered by a security interest. ${ }^{103}$ Our inclination derives not so much from "ostensible ownership" concerns (we do not think that a person who extends credit to a debtor somehow is entitled to rely upon the debtor's possession of assets as an indication that they are unencumbered), but rather from the belief that the public record effectively can impart useful information about the potential existence of a security interest. ${ }^{104}$ Thus, we would be inclined to require that a secured party file a proper financing statement as a condition to achieving priority over those third parties who are likely to make decisions on the basis of the kind of information contained in the financing statement. On the other hand, we would question the imposition of a filing requirement as a condition to achieving priority over those third parties for whom ready access to the information is of insignificant value. Third parties who are unlikely to have relied on the information contained in a financing statement or on the absence of a financing statement in the public record probably will not be injured by the secured party's failure to disclose publicly a preexisting security interest. As to those third parties, the failure to make a proper filing should not affect priorities.

Our experiences and the considerable anecdotal evidence of which we are aware lead us to think that potential secured parties (other than perhaps those taking purchase money security interests) generally are concerned about the state of the debtor's title when they extend secured credit and generally rely on the filing system to determine whether any other security interest has been granted in the collateral. ${ }^{105}$ The same is true for buyers of the collateral, who can be expected to give value in reliance on the debtor's ability to give good title and who often verify that the they

103 Although the text speaks in terms of a filing system, we would have no a priori objection to an alternative system of public notice.

104 See Douglas G. Baird, Notice Filing and the Problem of Ostensible Ownership, $12 \mathrm{~J}$. Legal Stud. 53, 58 (1983); see also Mooney, supra note 97, at 749-51 (arguing that filing requirement reduces costs of discovering interests in collateral).

105 This concern not only is a function of the first-to-file-or-perfect rule of U.C.C. $\S 9$ $312(5)(a)$, but also is consistent with normal rules of personal property conveyancing. Under those rules, the debtor would be able to convey no greater rights than it has. Having granted a security interest to SP-1, any security interest that the debtor might grant to SP-2 would be in property subject to SP-1's security interest. 
will receive unencumbered property by checking the public records. ${ }^{106}$

Unsecured creditors are in a somewhat different position. Because tort victims do not choose their tortfeasors (at least not in any meaningful way), whether a security interest is disclosed in the public record (or otherwise) seems irrelevant to that class of creditors. ${ }^{107}$ As for contract creditors, actual reliance on the state of the debtor's title to particular assets at the time credit is extended would be foolhardy. The debtor remains free to encumber all its assets moments after receiving the unsecured credit. ${ }^{108}$

To a considerable extent, current law reflects the view that buyers and secured parties are "reliance" parties who part with value in exchange for an interest in specific property, whereas judicial lien creditors are "non reliance" parties who have bargained for the right to enforce a judgment against whatever property the debtor may have on hand at the time. The law protects reliance parties by enabling them to acquire greater rights than their transferor has. ${ }^{109}$ In contrast, the title that nonreliance parties (including judicial lien creditors) acquire is typically no greater than the debtor's. ${ }^{110}$

Insofar as the public notice system is concerned, the reliance concept need not be limited to circumstances under which a creditor extends credit in exchange for an interest in particular property.

106 See U.C.C. § 2-312 (providing that seller of goods warrants good title).

107 The public record arguably has some relevance to tort creditors who obtain judgments against the debtor and seek to determine whether unencumbered property is available for satisfaction of the judgments.

108 A creditor who wishes to bind the debtor to a covenant restricting secured debt, however, may obtain useful information from the public record.

109 Most of the good faith purchase rules of the U.C.C., under which certain third parties acquire interests in property free of preexisting interests, benefit only reliance parties, such as buyers and secured parties, and not judicial lien creditors. See, e.g., U.C.C. § 2-403(1) ("A person with voidable title has power to transfer good title to a good faith purchaser for value."); id. § 3-302(c) (barring person who acquires negotiable instrument by legal process from becoming holder in due course); see also U.C.C. §1-201(32), (33) (defining "purchaser[s]" as only those who take by voluntary transactions).

One plausibly might question whether a secured party whose security interest extends to after-acquired property is really a "reliance" creditor. The answer may depend on the context. A secured financer of inventory and accounts generally would rely on the continued existence of a shifting mass of collateral to secure a series of advances, without advancing funds in reliance upon a particular item of inventory or a specific account. A secured creditor who lends against "all assets" may rely less.

110 See, e.g., Oswego Starch Factory v. Lendrum, 10 N.W. 900 (Iowa 1881). 
Information concerning the state of the debtor's title to property may bear little relevance to the ability of an unsecured creditor to acquire a lien on specific property in the future, but the information may be relevant nevertheless to the decision whether to extend (or continue to extend) credit. In some industries, the fact that a debtor has encumbered certain assets (often accounts receivable or inventory) is a signal that the debtor is in financial trouble. Sometimes the identity of the secured party may indicate financial health. ${ }^{11}$ We are told that unsecured creditors, either directly or through trade organizations, of ten seek information from and react to the information contained in the public records in deciding whether to commence or continue the extension of unsecured credit. If this is the case, then the creditors' behavior lends support to a rule along the lines of U.C.C. section 9-301(1)(b), which affords good-faith-purchase treatment to judicial lien creditors by subordinating an unperfected security interest to "the rights of a person who becomes a lien creditor before the security interest is perfected."112 But if the filing system is essentially irrelevant to unsecured creditors, then we would support reversal of the rule so that, insofar as a judicial lien creditor is concerned, an unperfected security interest would be treated exactly like any other interest in property in which the debtor also has an interest. That is, a judicial lien would attach to whatever interest in property the debtor enjoyed and thus would be subordinate to an unperfected security interest.

In a recent article, ${ }^{113}$ Professor James J. White has proposed an amendment to Article 9 in order to achieve just that result: namely, White argues for repeal of U.C.C. section 9-301(1)(b), which subordinates unperfected security interests to the rights of lien creditors. ${ }^{114} \mathrm{He}$ bases his argument on savings that could be achieved by eliminating two kinds of wasteful costs. First, some secured creditors would save the costs of compliance with the filing system.

111 The market for secured financing is stratified to the extent that some financers are known to serve primarily high-risk debtors, while others are known to serve primarily healthy entities.

112 U.C.C. § 9-301(1)(b).

113 James J. White, Revising Article 9 To Reduce Wasteful Litigation, 26 Loy. L.A. L. Rev. 823 (1993).

114 U.C.C. § 9-301(3) (“" ‘L]ien creditor' means a creditor who has acquired a lien on the property involved by attachment, levy or the like."). 
These creditors would be willing to take their chances against competing secured creditors and buyers so long as protection against the bankruptcy trustee would be ensured. Second, society would save the costs of litigation over issues of perfection. Against these potential savings, White explains that one must weigh the costs that his rule would impose on unsecured creditors who have no lien. He discounts the existence of "real" lien creditors as rare birds, while noting that unsecured creditors are the actual beneficiaries under current law because trustees in bankruptcy can avoid unperfected security interests for the benefit of unsecured creditors. ${ }^{15}$ White finds it unlikely that the costs imposed on essentially nonreliance unsecured creditors would outweigh the savings that his rule would produce.

Resolution of this issue ultimately turns on empirical evidence concerning the use to which unsecured creditors do put and would put information concerning security interests created by their debtors. This evidence, at least as of now, is available only in anecdotal form. ${ }^{116}$

The extent to which secured transactions actually give rise to ostensible ownership problems or present the opportunity for sham transactions has important policy implications, as does the impor-

115 See Bankruptcy Code $\S 544($ a) (giving trustee in bankruptcy the rights of a hypothetical lien creditor who has extended credit and acquired a judicial lien at the time a bankruptcy case is filed). White surveyed 888 reported decisions concerning $\S 544(\mathrm{a})$, finding 343 cases that would not have been litigated were it not for the fact that U.C.C. \$ 9301(1)(b) subordinates unperfected security interests to the rights of a lien creditor. White, supra note 113 , at $830-31$.

116 We suspect that additional empirical studies could provide useful information to those who deal with the law of debtors and creditors. Studies of debtors who have filed under the Bankruptcy Code tell us nothing about the effects of the Bankruptcy Code and nonbankruptcy law outside of bankruptcy.

Pending resolution of the empirical question, there is arguably a plausible middle road that would take into account claims that some unsecured creditors do rely on the filing records in their extensions of credit. To offset the repeal of U.C.C. \$ 9-301(1)(b), fraudulent transfer law could be revised to render a security interest avoidable if the secured creditor intentionally fails to attempt perfection (filing). We would expect that almost all secured creditors would file under that legal regime, with the result that third parties (including unsecured creditors) could rely on complete filing records almost to the same extent as under current law. On the other hand, this approach would avoid at least some costs of litigation that concern White and would eliminate some windfall that may exist under current law for nonreliance unsecured creditors. To the extent that trustees in bankruptcy would be encouraged to seek avoidance of unperfected security interests as fraudulent transfers, the savings would, of course, be reduced. 
tance of public notice to unsecured creditors. But regardless of the conclusions one reaches on these issues, one is not drawn to the conclusion that the law should prohibit secured transactions outright, treat them as fraudulent in all cases, impede the creation of security interests, or create traps to defeat the expectations of the debtor and secured party. Rather, public notice, perhaps coupled with other low-cost devices for deterring sham transactions, ${ }^{117}$ seems adequate to address these fraud-related externalities. ${ }^{118}$ If filing systems are not up to the task, they should be improved. ${ }^{119}$ If the drafters of the new Article 9 believe that needed improvements will not be forthcoming, then adjustments in the substantive rules of Article 9 may be warranted. ${ }^{120}$ But we seriously doubt that the shortcomings of the Article 9 filing systems could justify the prohibition of secured credit or a general policy of making the creation of effective security interests more difficult.

There is, however, a third aspect to the pre-U.C.C. treatment of nonpossessory security interests as fraudulent transfers-one that public notice arguably does not address. In many cases, whether the alleged transaction actually occurred (in the sense that the debtor and putative secured party reached some agreement concerning the collateral) is not the issue; rather, the issue is the true nature of the transaction that occurred and whether that nature is consistent with what the parties assert its nature to be. Consider Twyne. The problem appears to be not that Pierce and Twyne con-

117 For example, the requirement of a signed security agreement reasonably identifying the collateral. See U.C.C. $\S \S 9-110,-203(1)(a)$.

118 When one begins with the principle of free alienability of property, one sees Article 9 not as an institution that facilitates secured credit, but rather as a collection of impediments to the creation of effective security interests (e.g., in the filing rules and in the requirement of a signed security agreement). Repeal of Article 9 would leave secured transactions in the hands of fraudulent transfer law, which, presumably, would leave many "secret" security interests intact in the absence of fraudulent intent. See UFTA $\S 4(b)(2)$, 7A U.L.A. 652-53 (1984). On the other hand, the UFTA was promulgated in the shadow of current Article 9 public notice rules; in the absence of a filing requirement for nonpossessory security interests, fraudulent transfer law might view those arrangements with more skepticism.

119 A subcommittee of the Committee on Uniform Commercial Code, National Conference of Commissioners on Uniform State Laws, has assembled experts (including filing officers, information technology specialists, and lawyers) who are now working toward improvements in the filing systems.

120 For example, Article 9 could be revised so as to place greater burdens of accuracy and completeness on secured parties who give public notice. 
cocted a story after the fact, but that the transaction itself was not what it purported to be. The same problem arose with respect to the assignment of an interest in intangibles in Benedict $v$. Ratner. ${ }^{121}$ The Supreme Court struck down as fraudulent a financing arrangement under which the debtor was permitted to collect the collateral (accounts receivable) and use the proceeds in the ordinary course of business without accounting to the secured party. The fraud consisted of "the reservation [by the debtor] of dominion inconsistent with the effective disposition of title and creation of a lien."122 Affording the debtor the unrestrained right to cause the collateral to disappear seemed inconsistent with the concept of security implicit in the Court's opinion: the concept that particular property should be devoted to securing payment of a particular debt. ${ }^{123}$ In other words, in Benedict as in Twyne, the perceived inconsistency between what the debtor did and what the debtor said it was doing led the Court to conclude that the purported financing arrangement was a sham. The Court observed that "[t]he existence of the assignment was to be kept secret,"124 but we doubt that the result would have changed had the parties publicized the assignment. ${ }^{125}$ Public notice would not have increased the lender's dominion over the accounts.

The discomfort that some critics experience with the "all assets" security interest may be related to the concerns expressed in Benedict. Like the lender there, the all-assets lender arguably does not bargain for or rely upon the continued existence of specific assets (or even, in the case of inventory and accounts, the availability of their proceeds or substitutes). Rather, as in Twyne, the debtor enjoys the use of the collateral as if it were unencumbered; other creditors, however, are effectively precluded from reaching those assets. It is as if the secured party simply sits back until financial

121268 U.S. 353 (1925), superseded by U.C.C. § 9-205. As the Court correctly observed, any fraud concerning assignments of intangibles, which by their nature cannot be possessed or observed, could not derive from misleading appearances. Benedict, 268 U.S. at 362-63.

122 Benedict, 268 U.S. at 363.

123 This concept is the essence of the prototypical secured transactions-the real estate mortgage and the pledge.

124 Benedict, 268 U.S. at 360.

125 See 1 Gilmore, supra note 2, at 39-47 (discussing cases holding chattel mortgages covering a debtor's "stock in trade" (i.e., inventory) to be fraudulent notwithstanding recording under chattel mortgage acts). 
trouble arises and then lays claim to whatever property might be available at the time. An arrangement of this kind looks more like a promise to afford priority in payment-a promise that the law does not enforce-than a lien on specific property. ${ }^{126}$ Alternatively stated, the secured party who gives the debtor a free hand appears not to have earned its place at the head of the line.

This argument overlooks at least two key considerations. First, the existence of easily obtained security is not inconsistent with the law's general refusal to enforce a debtor's contractual promise to prefer particular creditors (i.e., to pay them rather than other creditors). The disappointed obligee needs no remedy. It would retain the right to recover its unpaid claim from the debtor; the debtor's failure to make a preferential payment would not give rise to additional damages. And the refusal to enforce a promise to prefer against a competing creditor who has received the funds is fully consistent with general legal principles of finality of payment and negotiability of money.

Second, we see nothing unfair or untoward about permitting a secured creditor to go to the head of the line when earlier-in-time creditors have not chosen to obtain security themselves and all creditors have an opportunity to discover the existence of the secured creditor. Objections to all-assets financing fail to take into account that the totality of the relationship between the all-assets financer and the debtor may produce additional benefits to the debtor and its other creditors. ${ }^{127}$ In addition, all-assets secured creditors may rely substantially on the hard liquidation value of the debtor's assets even though the transaction may not be asset based to the same extent as a loan secured by accounts receivable or inventory that incorporates a "borrowing base."128

This last aspect of the pre-U.C.C. treatment of nonpossessory security interests-skepticism that a purported secured transaction is not what the parties assert it to be-may lie at the core of the SLS concern that secured credit jeopardizes the existence of a

126 Although the law will not enforce an agreement between the debtor and a particular creditor under which the debtor promises to afford the creditor priority in distribution, it will enforce a subordination agreement, i.e., an agreement by one creditor to subordinate its right to payment to that of another creditor.

127 See Scott, supra note 10.

128 See supra note 57 and accompanying text (discussing borrowing base). 
"cushion" of free assets available to the unsecured creditors of an insolvent debtor. If revisions to Article 9 make effective security interests even easier to create, then the cushion may disappear entirely. Like throwing the switch that illuminates the Christmas tree at Rockefeller Center, one flick of the wrist will subordinate all unsecured creditors to the all-assets secured creditor. We addressed this concern at length in Part I. As we explained there, based on the assumptions that the law will not prohibit security interests and that in many cases credit will be extended only if security is given, the effects of secured credit on the unsecured creditors of insolvent debtors tell us nothing conclusive about whether secured credit benefits or harms unsecured creditors generally. Secured credit may provide net benefits to unsecured creditors and society generally, even though secured creditors take all the marbles when a debtor becomes insolvent.

Even if one perceives a need to create a pool of unencumbered assets, making secured credit more uncertain is an odd way to achieve this goal. Suppose one can determine, for example, that five percent of secured claims will be avoided, year after year. Why not avoid every twentieth secured claim, or five percent of each secured claim, thereby eliminating costly litigation about issues of perfection? ${ }^{129}$ If secured creditors are repeat players, and if the perfection errors that lead to subordination under U.C.C. section 9-301(1)(b) and avoidance under Bankruptcy Code $\S 544(\mathrm{a})$ are unlikely to impose costs on unsecured creditors, then a random approach of this kind may make more sense than the somewhat random approach of current law. ${ }^{130}$

Fraudulent transfer law and public notice requirements are not necessarily the only appropriate restrictions on the creation of effective security interests. For example, there are plausible arguments for limiting the ability of certain debtors, such as consumers,

129 Professor Shupack suggested to us (perhaps as an illustration of the point we make in the text) the possibility that a bankruptcy "tax" on all secured claims might be assessed in order to pay administrative expenses and a portion of unsecured claims. Professor Shupack contemplated that, in exchange for the "tax," trustees in bankruptcy (and debtors in possession) would cease to nitpick security interests.

130 The facts that some secured creditors are not repeat players and that others take special care to comply with perfection requirements weigh against an approach of this kind. 
to encumber easily all of their existing and future assets ${ }^{131}$ or to give security interests that will be used primarily for "hostage" value. $^{132}$ And there is a host of other secured-credit-related consumer protection provisions under a variety of federal and state laws. ${ }^{133}$ Professor Lynn LoPucki would take these restrictions a step further in the case of a secured creditor's priority over unsecured creditors. He would permit a secured creditor to achieve priority only to the extent that the priority was within the unsecured creditor's "reasonable ... expect[ation]." "134 But neither LoPucki's concerns nor those that underlie the various consumer protection laws cast any general shadow on secured credit as an institution.

131 See, e.g., U.C.C. § 9-204(2) (limiting effect of after-acquired property clauses covering consumer goods).

132 See FTC Credit Practices Rule, 16 C.F.R. § 444.2(a)(4) (1994) (providing that taking a nonpossessory, non-purchase-money security interest in household goods is an "unfair act or practice" under Federal Trade Commission Act § 5, 15 U.S.C. § 45 (1988)).

133 See, e.g., Board of Governors of the Federal Reserve System Regulation Z, 12 C.F.R. § 226.18(m) (1994) (mandating disclosure of security interest in closed-end credit transaction); Unif. Consumer Credit Code §§ 3.301-.303, 7A U.L.A. 116-19 (1974) (restricting the taking of security interests and cross-collateralization).

134 LoPucki, supra note 5, at 1948. Although LoPucki calls only for an adjustment in priorities and during the Charlottesville conference denied any association with the Symps, his article is largely an attack on the institution of secured credit within the best traditions of SLS: "The institution of security has a . . bad reputation. Its most persistent image is that of families forced from home or farm through foreclosure. Most noneconomists wish that things could be different. We are rooting for the underdog, which means we are rooting against security." Id. at 1888-89 (footnote omitted). He adds: "Two promising malignant explanations for the existence of secured debt were commonly noticed but rarely explored. Security might be flourishing because it facilitates the exploitation of involuntary creditors or of voluntary creditors who failed to react to security." Id. at 1895.

The analysis in Part I, supra, indicates that whether secured credit benefits or injures unsecured creditors turns on specific facts. One might wish to create a regime in which security interests were effective only against those unsecured creditors who could, in Professor LoPucki's words, "react to security." Id. Toward that end, one might fashion a rule that subordinates security interests to the rights of any unsecured creditor who, upon investigation, is determined to be unable to react to security. A more feasible approach would be to subordinate security interests to certain discrete classes of creditors whose members are likely to be unable to react (e.g., tort victims). For an argument against creating such a regime, see White, supra note $* *$. A balanced consideration of tort claims also should take account of their adverse effects on other creditors of insolvent tortfeasors. An insolvent tortfeasor who incurs an obligation to a tort victim typically does not receive reasonably equivalent value in exchange for the obligation. Arguably, the tortfeasor's obligation is avoidable under UFTA § 5(a), 7A U.L.A. 657 (1984). 


\section{Security Interests and Bankruptcy Policy}

As we discussed in Part I, the questions and concerns raised by both the Efficiency Literature and SLS stem primarily from the distributive effects of secured credit when a debtor becomes insolvent. Most insolvent debtors do not become the subject of a bankruptcy case or other formal insolvency proceeding. Nevertheless, the relative rights of secured and unsecured creditors in bankruptcy has consumed thousands of law review pages. Concerns about the effect of bankruptcy on the effectiveness of security interests are not peculiar to the academy. A principal motivation for taking security is the desire to increase the likelihood of payment in the event of bankruptcy. The purposes and benefits of giving and taking security would be undermined considerably if security interests were not generally honored in bankruptcy.

The discussion in Part I, in which we argued that secured credit may be beneficial not only to the secured party and debtor but also to unsecured creditors, takes account of the distributive rules of bankruptcy. In this Part we examine two possible bases for tension between bankruptcy policy and a property-based normative theory of secured transactions that generally gives effect to security interests. First, bankruptcy policy might conflict with honoring a debtor's prebankruptcy transfers of property generally. Second, there might be something special about security interests that gives rise to a conflict with bankruptcy policy. We conclude that there is no conflict of either kind. For purposes of this discussion, we take the Bankruptcy Code as our primary source of information about bankruptcy policy. We do not undertake to develop a normative theory of bankruptcy. ${ }^{135}$

135 The following sketch of the Bankruptcy Code's policies toward nonbankruptcy property transfers is consistent with the idea that, at least as a baseline, bankruptcy law should honor nonbankruptcy entitlements. Although most scholars are likely to agree with this general idea as a normative matter, disagreements have arisen concerning the proper normative bases for deviating from this baseline. Compare Douglas G. Baird \& Thomas H. Jackson, Corporate Reorganizations and the Treatment of Diverse Ownership Interests: A Comment on Adequate Protection of Secured Creditors in Bankruptcy, 51 U. Chi. L. Rev. 97, 100 (1984) (arguing that nonbankruptcy entitlements and loss distribution rules should be respected in bankruptcy unless collective wealth maximization for creditors dictates otherwise) with Elizabeth Warren, Bankruptcy Policy, 54 U. Chi. L. Rev. 775, 79093 (1987) (rejecting creditor wealth maximization as the sole relevant factor and arguing that several conflicting values should determine loss distributions in bankruptcy). The 
Certainly no conflict arises between the Bankruptcy Code's basic policies and either the general respect the Code affords to the debtor's prebankruptcy transfers of property (including security interests) or the corresponding respect the Code shows for the rights of those (including secured parties) who have property interests that do not belong to the debtor. Indeed, respect for nonbankruptcy property interests lies at the heart of the Bankruptcy Code. The Code provides that property of the estate includes "[a]ll legal or equitable interests of the debtor in property." 136 It affords "adequate protection" to others who have an interest in property of the estate (including secured creditors) ${ }^{137}$ and generally requires that property claimants recover their property or its value before the conclusion of the case. ${ }^{138}$ Moreover, in determining the nature and extent of property interests, the Bankruptcy Code generally defers to state (and other nonbankruptcy) law, which includes Article 9.139

policy arguments thus focus on the details, such as the right of an undersecured creditor to receive postpetition interest on the value of collateral as adequate protection from the automatic stay of repossession and foreclosure. See United Sav. Ass'n v. Timbers of Inwood Forest Assocs., 484 U.S. 365 (1988) (resolving this issue, once the subject of conflicting opinions in the Courts of Appeals, against the undersecured creditors). We do not trivialize these details. Some commentators, practitioners, and businesspeople believe strongly that the Bankruptcy Code has eviscerated secured financing, and others hold an equally strong belief that the Code is far too "soft" on secured claims. We do not join that debate but suggest that, for many of the reasons discussed in Part II, supra, those who would treat security interests differently from other property interests and other prebankruptcy transfers must provide some principled basis for that distinction.

136 Bankruptcy Code $\S 541$ (a)(1) (emphasis added).

137 Bankruptcy Code $\S 361$ (covering "adequate protection"); § 362(d)(1) (providing for relief from automatic stay for failure to provide adequate protection); § 363(e) (prohibiting use, sale, or lease of property unless adequate protection is provided to entity with an interest in the property); §364(d)(1)(B) (requiring adequate protection for lienholder when property is subjected to equal or senior lien pursuant to postpetition financing).

138 See, e.g., Bankruptcy Code $\S 365(\mathrm{~b})(1)$ (protecting nondebtor party to unexpired lease of property); $\S 725$ (regulating disposition of property in which an entity other than the estate has an interest).

139 Because Bankruptcy Code $\S 541$ (a)(1) is part of a federal statute, the meaning of the phrase "legal or equitable interests of the debtor in property" is a question of federal law. Nevertheless, in construing this phrase, courts take the approach of In re Farmers Markets, 792 F.2d 1400 (9th Cir. 1986): Bankruptcy Code $\S 541(\mathrm{a})(1)$ "does not address the threshold questions of the existence and scope of the debtor's interest in a given asset. Under both the [Bankruptcy] Act [of 1898] and the [1978 Bankruptcy] Code, we resolve these questions by reference to nonbankruptcy law." Id. at 1402 (citations omitted). 
We see nothing in the Bankruptcy Code that suggests any animus toward prebankrupicy transfers generally. And, although the Bankruptcy Code explicitly recognizes and makes provision for secured claims, ${ }^{140}$ for the most part it does not single out secured transactions. For example, the rules concerning adequate protection are, at least by their terms, agnostic as to the kind of property interest that is involved. The same is true for the major avoidance powers. ${ }^{141}$ To a considerable extent, the avoidance powers build upon nonbankruptcy law. ${ }^{142}$ One principal exception is the bankruptcy trustee's power to avoid certain preferential prebankruptcy transfers that would be wholly effective and unobjectionable under state law. ${ }^{143}$ But the avoidance of preferences applies to all forms of transfer, including payments; it does not discriminate against security interests. ${ }^{144}$

140 Bankruptcy Code $\S 506$.

141 See, e.g., Bankruptcy Code $\S \S 544,547,548$.

142 For example, Bankruptcy Code $\S 544(\mathrm{a})$ defers completely to applicable nonbankruptcy law for the rights of a hypothetical lien creditor, as does $\S 544$ (b) for the avoidance powers of an actual creditor. Although $\S 548$ has been held to create a federal law of fraudulent transfer for bankruptcy purposes, its principles are consistent with those of state law. Compare Bankruptcy Code §548(a)(1) (actual fraud) and § 548(a)(2) (constructive fraud) with Unif. Fraudulent Conveyance Act § 7, 7A U.L.A. 509 (1918) (actual fraud) and $\S \S 4-6,7 A$ U.L.A. 504-07 (1918) (constructive fraud) and UFTA $\S 4(a)(1), 7 A$ U.L.A. 652 (1984) (actual fraud) and $\S \S 4(a)(2), 5(a), 7 A$ U.L.A. 653, 657 (1984) (constructive fraud).

143 See Bankruptcy Code $\$ 547$. The two most commonly proffered explanations of preference law relate to distributional concerns (i.e., that preference law promotes equality of treatment among creditors) and to wealth maximization (i.e., that it deters creditors from diminishing the going-concern value of the debtor by stripping away assets). See, e.g., John C. McCoid, II, Bankruptcy, Preferences, and Efficiency: An Expression of Doubt, 67 Va. L. Rev. 249, 260-61 (1981). Although McCoid refers to maximization of the debtor's estate as "an infrequently stated companion goal," id. at 261, more recent scholarship has emphasized this goal more than equality of distribution. See Steven L. Harris, Deterrence, Equality and Preferences: A Challenge to Current Theories (unpublished manuscript, on file with the Virginia Law Review Association). One of us has suggested elsewhere that the treatment of security interests under Bankruptcy Code $\S 547$ appears more concerned with blunting the advantage that particular creditors might otherwise enjoy than with preventing wealth-destroying "last-minute grabs" by secured parties. Id. at 33.

144 If anything, certain exceptions to avoidance are deferential to the transfer of security interests. See Bankruptcy Code $\S 547$ (c)(3) (excepting from avoidance certain purchasemoney security interests); $\$ 547$ (c)(5) (excepting from avoidance certain security interests in inventory, receivables, and the proceeds of either). 
Say what one will about whether the drafters of Article 9 facilitated the creation of secured credit more than they could have imagined. But the Bankruptcy Code was drafted in the shadow of Article 9, with Article 9's explicit rejection of the rule of Benedict v. Ratner ${ }^{145}$ and explicit validation of after-acquired property clauses. ${ }^{146}$ By the mid-1970s the practical implications of Article 9 were clear: a multitude of borrowers and lenders had entered into Article 9 transactions, including loans secured by all assets of the borrower. Congress clearly left the door open for secured creditors to take everything in bankruptcy.

Nothing in the Bankruptcy Code instructs the drafters of the new Article 9 to make secured credit less available, more expensive, or more risky. But SLS would do just that. In their preoccupation with the putative impact of secured claims on the cushion of "free" assets (or the absence thereof) available for unsecured creditors, the Symps identify a dark side to secured credit. ${ }^{147}$ We submit that unsecured creditors of insolvent debtors go unpaid in bankruptcy because their debtors have gone broke. To blame their plight on secured credit makes no more sense than to blame insolvencies on tort victims who buy defective products or on the public generally for not buying enough of a debtor's product at a high enough price to enable the debtor to turn a profit. ${ }^{148}$ As we explained elsewhere, ${ }^{149}$ even if secured creditors were to take everything in every insolvency, that would tell us nothing about whether secured credit is beneficial to unsecured creditors or society generally. The Symps' claim that "everyone must share the pain" when the debtor

145 U.C.C. $\S 9-205$.

146 Id. $\S 9-204(1)$.

147 There are other related, but distinct, approaches. One suggests that bankruptcy is a common disaster in which all creditors must share to a greater or lesser extent. See, e.g., Thomas H. Jackson \& Robert E. Scott, On the Nature of Bankruptcy: An Essay on Bankruptcy Sharing and the Creditors' Bargain, 75 Va. L. Rev. 155 (1989); cf. United Sav. Ass'n v. Timbers of Inwood Forest Assocs., 484 U.S. 365, 378-79 (rejecting the argument that, under the Bankruptcy Code, "secured creditors do not bear the costs of reorganization"). The other approach emphasizes the desirability of reducing in bankruptcy any nonbankruptcy advantage that one creditor may enjoy over another. See Harris, supra note 143, at 29-38.

148 Secured parties who are in fact blameworthy-those who have engaged in inequitable conduct that injures other creditors-may find their claims subordinated under principles of equitable subordination. See Bankruptcy Code $\S 510(c)$.

149 See supra Part I.B. 
enters bankruptcy is not a sound basis for an indictment of secured credit or a justification for generally redistributing the property of secured creditors to others. Even if bankruptcy law were to adopt that unsubstantiated claim, the claim still would need to be operationalized in a principled manner-something the Symps have not even attempted to do. Doing so would require them to take account of how making security interests less valuable in bankruptcy would reduce the availability of secured credit, to the detriment of the very unsecured creditors that the Symps think they are helping.

\section{CONCLUSION}

We respect the efforts that have produced the Efficiency Literature, and we appreciate the Symps' instinctive desire for equitable allocation of the social burdens of insolvency. In this Article, however, we have tried to explore the connection, if any there be, between the prevailing academic agendas and the world of law reform. The facts, as they appear to us, are these. Article 9 will be revised within the next three years. Over the last fifteen years the Efficiency Literature has produced few proposals for changes in the law. ${ }^{150}$ Its principal message has been to advocate the status quo, based on perceived benefits of secured credit or uncertainty sufficient to discourage tampering with a well-settled legal institution. SLS appears not to have been influenced materially by the Efficiency Literature (if anything, Symps may take heart at the indeterminacy highlighted in the Efficiency Literature). Although the shadow cast by SLS over the institution of secured credit is ubiquitous, SLS has come forward with no coherent and principled basis on which to question the benefits of secured credit. And both the Efficiency Literature and SLS have been led astray by the myth that secured credit necessarily has adverse effects on unsecured creditors.

In taking issue with a number of our material points and with our conclusions, Professor Schwartz asserts that we have "fail[ed]

150 There are exceptions. See, e.g., Buckley, supra note 10, at 1460-69 (questioning superpriority for purchase-money security interests and priority for holders in due course of negotiable instruments); Schwartz, supra note 6 (proposing reforms to the Article 9 and bankruptcy priority schemes). 
to take the analysis of security seriously." 151 Most readers easily will see that by this phrase Schwartz means that we have failed to approach his "puzzle" of secured credit on his terms and in the manner he and some other contributors to the Efficiency Literature previously have chosen to address the subject. Instead, we have based our analysis on two assumptions that we do not believe can be seriously questioned: that something like security interests will continue to be an important feature of our legal landscape, and that much credit would not be extended without security. Given these assumptions, we have explored whether the extension of secured credit to a debtor necessarily is harmful to the debtor's unsecured creditors, as some (including Schwartz) have assumed. ${ }^{152}$ Professor Schwartz' critique fails to shake our conclusions. To the contrary, we are gratified that Schwartz apparently has conceded that the question is an empirical one. ${ }^{153}$

We see secured transactions as a subset of property law and secured credit as one species of exchange for value. Our view not only draws normative support from the widely accepted respect that the law affords party autonomy, but also exposes the incoherence of SLS. Perhaps our view can provide a useful baseline for the drafters of the new Article 9. At a minimum, we hope that it stimulates discussion.

151 Schwartz, supra note ${ }^{* *}$, at 2086.

152 Most of Professor Schwartz' errors derive from his failure to take seriously or understand these assumptions. Two examples will suffice. Schwartz chides us for not making progress with his puzzle, id. at 2080, but we have declared our intention not to address his puzzle on his terms, see, e.g., supra note 19. Professor Schwartz also claims that we have ignored certain factors, such as information asymmetry and market imperfections, that bear on the debate. Of course, we do consider these issues in Part II.B, supra. These factors generally are addressed by the current regime through public notice rules, fraudulent transfer law, and the like. Once they have been dealt with, there are no relevant fundamental distinctions between secured transactions and other voluntary transactions, as we have shown.

153 His claim to have answered the question conclusively with his "armchair empiricism," however, is far-fetched. See Schwartz, supra note *:k, at 2078. Schwartz is correct in attempting to distinguish fact from theory, but if he is wrong on his empirical point he has little theory left with which to work. 